\title{
Public Investment in Resource-Abundant Developing Countries
}

\author{
ANDREW BERG, RAFAEL PORTILLO, SHU-CHUN S. YANG, and \\ LUIS-FELIPE ZANNA*
}

Natural resource revenues provide a valuable source to finance public investment in developing countries, which frequently face borrowing constraints and tax mobilization problems. This paper develops a dynamic stochastic model to analyze the macroeconomic effects of investing resource revenues, making explicit the role of public investment inefficiency, absorptive capacity constraints, Dutch disease, and financing needs to sustain capital. Revenue exhaustibility raises medium-term issues of how to sustain capital built during a windfall, while revenue volatility raises short-term concerns about macroeconomic instability. Using the model, country applications show how combining public investment with a resource fund - a sustainable investing approach-can address the problems associated with exhaustibility and

\footnotetext{
*Andrew Berg is Assistant Director and head of the Development Macroeconomics Division in the IMF's Research Department. Rafael Portillo, Shu-Chun Yang and Luis-Felipe Zanna are Senior Economists in the Development Macroeconomics Division of the IMF's Research Department. This paper was previously circulated under the title "Public Investment in Resource Abundant Low-Income Countries." The authors acknowledge comments by Chris Geiregat, Jan Gottschalk, Saul Lizondo, Sean Nolan, Catherine Pattillo, Frederick van der Ploeg, Mauricio Villafuerte, and seminar participants in the African Department of the IMF, the IMF/CBRT Conference on Policy Responses to Commodity Price Movements, Bank of Canada, and the Emerging Market Risk Management Conference. The authors are particularly grateful to PierreOlivier Gourinchas, Gulcin Ozkan, and two anonymous referees for very constructive comments. Finally, they thank Christine Richmond and Irene Yackovlev for assistance on the Angola application, and Christophe Hurlin for providing data to calibrate investment efficiency parameters. This paper is part of a research project on macroeconomic policy in low-income countries supported by U.K.'s Department for International Development. The views expressed herein are those of the authors and should not be attributed to the IMF, its Executive Board, its management, or of DFID.
} 
volatility. The applications also demonstrate how the model can be used to determine the appropriate magnitude of the investment scaling-up (accounting for the financing needs to sustain capital) and the adequate size of a stabilization fund (buffer). [JEL Q32, E22, F43, O41]

IMF Economic Review (2013) 61, 92-129. doi:10.1057/imfer.2013.1;

published online 2 April 2013

$\mathrm{N}$ atural resource revenues have been an important source of fiscal revenue and foreign exchange in many developing countries. The International Monetary Fund lists 29 resource-rich developing countries and 12 prospective countries with identified reserves (International Monetary Fund, 2012c). Among these, the average poverty headcount (living at \$2 a day or below) is about 60 percent, and only 27 percent of total roads are paved. ${ }^{1}$ Many of these countries face borrowing constraints and limited tax revenue mobilization. Recent surges in resource revenue may thus provide a valuable source to finance public investment, which is essential for economic development.

Managing revenues from nonrenewable resources poses challenges for policymakers. The conventional advice based on the permanent income hypothesis $(\mathrm{PIH})$ prescribes that off-the-ground resource wealth should be saved externally in a sovereign wealth fund (for example, Davis and others, 2001; Barnett and Ossowski, 2003; and Bems and de Carvalho Filho, 2011). While this advice preserves resource wealth and avoids instability from spending volatile revenues, it overlooks the current poor living conditions and investment needs in capital-scarce economies. Since mid-2000s, calls for reconsidering the conventional advice and prompting investment spending of resource revenue in developing countries have emerged (for example, UNC-TAD Secretariat, 2006; Sachs, 2007; Collier and others, 2010; Independent Evaluation Office, 2011; Baunsgaard and others, 2012; International Monetary Fund, 2012c). These calls have been supported by theoretical work demonstrating that productive government spending can dominate external saving as an optimal strategy to manage resource revenue in creditconstrained, capital-scarce economies (for example, Takizawa, Gardner, and Ueda, 2004; Venables, 2010; van der Ploeg, 2010a; van der Ploeg and Venables, 2011; and Araujo and others, 2012). ${ }^{2}$

\footnotetext{
${ }^{1}$ These statistics are the authors' estimates based on the data in Appendix 1 of International Monetary Fund (2012c). "Resource-rich" is defined as having the average natural resource revenue (or natural resource exports) of at least 20 percent of total fiscal revenue (respectively, total exports) over the period 2006-10.

${ }^{2}$ When borrowing costs and debt service are high, another optimal use of resource revenue is to pay down external debt as discussed in Daban and Helis (2010) and van der Ploeg and Venables (2011). This use, however, may be less empirically relevant in recent years. Owing to the debt relief under the Highly Indebted Poor Countries (HIPCs) Initiative and Multilateral Debt Relief Initiative substantially, debt burdens have substantially lowered in
} 
Despite the theoretical appeal of investing resource revenue, history has not generally supported that investing resource revenues would promote sustained economic growth. Resource-abundant countries tend to grow more slowly than others - the so-called natural resource curse. ${ }^{3}$ Gelb (1988) studies six oil-exporting developing countries (Algeria, Ecuador, Indonesia, Nigeria, Trinidad and Tobago, República Bolivariana de Venezuela) that undertook sizable investment projects between 1975 and 1978. The overall growth rate of non-oil output was higher after 1974 but quickly slowed after $1978 .{ }^{4}$ History then suggests that other factors - aside from potential high capital returns implied by capital scarcity and the relaxation of credit constraintscan matter for the outcome of investing a resource windfall.

This paper develops a model, in the tradition of the dynamic stochastic general equilibrium (DSGE) literature, to analyze the macroeconomic effects of public investment increases that are mainly financed by natural resource revenues. The model accounts for several important features that are common in developing countries, including public investment inefficiencies, absorptive capacity constraints, weak tax systems, and Dutch disease. Based on this framework, we propose a sustainable investing approach-a combination of raising public investment and saving some of the resources in a resource fund-that fulfills the development needs, preserves resource wealth, and maintains economic stability. This approach stands out then as a policy alternative to grapple with both exhaustibility and volatility issues associated with natural resource revenues.

Low public investment efficiency is pervasive among developing countries. Pritchett (2000) and Hurlin and Arestoff (2010) provide estimates of efficiency - defined as the ratio of the change in public capital to investment expenditures - which are generally below 0.5 for countries in sub-Saharan Africa and Latin America. If investment is scaled up quickly (as often observed during a windfall), absorptive capacity constraintsattributed to supply bottlenecks or poor planning - can drive up investment costs further, as discussed in Collier and others (2010), van der Ploeg (2012), and Buffie and others (2012). ${ }^{5}$ Following Arestoff and Hurlin's (2006)

most low-income countries (International Development Association and International Monetary Fund (2011)). The average debt service to GDP of the 36 HIPCs dropped from 3.1 percent in 2000 to 0.9 percent (or 3.9 percent of exports) in 2010 .

${ }^{3}$ The natural resource curse has been widely studied in the literature, for example, Gelb (1988), Sachs and Warner (1999), Sachs and Warner (2001), and van der Ploeg (2011) for surveys. While an average negative correlation exists between growth and the export share of natural resource, some countries, such as Botswana and Chile, have escaped the curse.

${ }^{4}$ Particularly in Venezuela, about 40 percent of the oil windfall went to public investment, including industrial development projects, education, health, electricity, water, highways, and so on. Yet the growth rate of per capita non-oil GDP declined in 1976 and became negative in 1979 (Moreno and Shelton, 2013).

${ }^{5}$ See Chapter II.A in InternationalMonetary Fund (2012d) for the underlying causes resulting in absorptive capacity constraints. 
estimates using Mexican data, we model that investment efficiency falls when investment expenditure levels exceed a threshold value.

The model captures Dutch disease effects through a learning-by-doing externality in nonresource production (van Wijnbergen, 1984): With the windfall, rising government spending can impose demand pressures on nontraded goods, leading to a real appreciation, and a decline in tradedgood production and the total factor productivity (TFP) in this sector. However, in our framework public investment can raise productivity in the nonresource traded sector, counteracting and eventually reversing the effects of Dutch disease, as suggested in Sachs (2007) and Berg and others (2010).

Two key distortions help explain why natural resource rents deserve special analysis in the context of public investment scaling-up. First, in our model - and typically in practice-low-income countries are limited in their ability to access international capital markets. Resource sectors are a major exception: Foreign direct investment (FDI) in resource extraction and related sectors is substantial in sub-Saharan Africa, for example, presumably because the high rents provide an incentive to overcome the difficulties implied by sovereign immunity and poor governance. Second, inefficient and weak domestic tax systems amplify the costs of self-financed public investment scaling-up and the deferred private consumption and investment that this strategy implies.

Our analysis consists of two country applications, which illustrate the sustainable investing approach.

The first application, to the CEMAC region (the Central African Economic and Monetary Community), stresses the importance of securing financing of recurrent costs for sustaining capital, when exhaustibility is looming in the next $10-20$ years. ${ }^{6}$ Decisions about whether to invest in domestic capital or to save in a sovereign wealth fund depend not only on the return to capital but also on the economy's absorptive capacity. But more importantly, even when investment is sufficiently productive, the magnitude of the investment scaling-up should be jointly assessed with the fiscal adjustment necessary to sustain capital beyond the windfall. Although largescale public investment programs can speed up economic development, ongoing expenditures to cover recurrent costs for operation and maintenance (to avoid faster capital depreciation by "filling the potholes") are crucial to have investment projects remain productive (Heller, 1974 and Rioja, 2003). By making explicit the financing needs to maintain capital, our sustainable investing approach suggests that, when revenue mobilization is difficult or the distorting effects of fiscal adjustments are large, the investment scalingup should be reduced. With a smaller scaling-up, more resource revenue can

\footnotetext{
${ }^{6}$ The CEMAC region consists of Cameroon, Central African Republic, Chad, Congo, Equatorial Guinea, and Gabon. See Caceres, Poplawksi-Ribeiro, and Tartari (2011) and Baker and Nxumalo (2013) for recent economic conditions and oil production activity in the CEMAC region. The average share of oil GDP was 38 percent of GDP in 2010 and is expected to decline to about a quarter of the current production level by 2030 .
} 
be saved in a resource fund, whose return helps finance recurrent costs, thus yielding long-term growth benefits from investing a windfall.

The second application, to Angola, underscores the importance in building a fiscal buffer to invest volatile revenue, as advised in Collier and others (2010), van der Ploeg (2010b), Cherif and Hasanov (2012), and Van den Bremer and van der Ploeg (2012). Fiscal responses to resource revenue can have a substantial impact on macroeconomic stability (Pieschacon, 2011). Large fiscal expansions from 2006 to 2008 in Angola, prompted by oil revenue surges, left the economy with little buffer when the oil price plummeted in 2008-09. By using the resource fund as a fiscal buffer, the sustainable investing approach instead can protect the economy from the boom-bust cycles driven by commodity price shocks. Stochastic simulations that account for historical volatility of oil prices demonstrate how our framework can assess the adequacy of a buffer given a scaling-up plan and inform allocations between investing and savings in facing uncertain revenue flows.

Among the burgeoning research on managing resource revenue in developing countries, our paper adds to the literature by constructing a fully specified dynamic stochastic framework that can be used for policy analysis. The papers previously cited provide useful benchmarks and insights on investing resource revenue from the perspective of optimal policy. The models used, however, are often simplified for tractability and focus on solving a social planner's problem. Moreover, they often endow governments with a set of fiscal tools that are capable to fully correct any kind of distortions (for example, internalize the effects of frictions such as absorptive capacity constraints or smooth consumption for hand-to-mouth consumers), but that may not be implementable in reality. ${ }^{7}$ Our model, instead, incorporates more fully the consumption, working, saving, and production decisions of private agents, while focusing on simple and implementable fiscal policies. A relatively detailed fiscal specification makes it feasible to simulate the effects of a given fiscal path or of simple fiscal rules in allocating resource revenues.

\section{Model Setup}

The model is a small open, real economy that has three production sectors: nontraded goods (nonresource) traded goods, and a natural resource. Our interest is in studying the macroeconomic effects of a resource-revenuefinanced public investment scaling-up in low-income or lower-middle income countries. We examine later alternatives involving greater reliance on tax finance, and explain why in practice the scope for nonresource tax

\footnotetext{
${ }^{7}$ For example, van der Ploeg (2010b), Bems and de Carvalho Filho (2011), and Cherif and Hasanov (2012) assume exogenous nonresource income; Venables (2010), Araujo and others (2012), and van der Ploeg, Stefanski, and Wills (2012) abstract from government or fiscal specifications; van der Ploeg (2010a), van der Ploeg and Venables (2011), and Arezki, Dupuy, and Gelb (2012) assume foreign financed private capital.
} 
increases to finance public investment is generally limited. Also, we abstract from debt-financed scaling-ups. Most governments in low-income and lower-middle-income countries have limited access to external commercial funds, particularly before the discovery of natural resource reserves. ${ }^{8}$ Moreover, reflecting financial development conditions in these economies, the model is assumed to have a closed private capital account, as a first approximation. ${ }^{9}$

\section{Households}

A representative household chooses consumption $c_{t}$ (a composite of goods) and labor $l_{t}$ to maximize expected utility,

$$
E_{0} \sum_{t=0}^{\infty} \beta^{t}\left[\frac{1}{1-\sigma}\left(c_{t}\right)^{1-\sigma}-\frac{\kappa}{1+\psi}\left(l_{t}\right)^{1+\psi}\right]
$$

subject to the budget constraint in units of domestic composite consumption:

$$
\left(1+\tau_{t}^{c}\right) c_{t}+b_{t}=\left(1-\tau_{t}^{l}\right) w_{t} l_{t}+R_{t-1} b_{t-1}+\Omega_{t}^{T}+\Omega_{t}^{N}+s_{t} r m^{*}+z_{t} .
$$

$E_{0}$ denotes the expectations operator conditional on information available at time $0 . \sigma$ and $\psi$ are the inverses of the elasticities of intertemporal substitution for consumption and labor supply, respectively. $\kappa$ is the disutility weight on labor. $w_{t}$ is a real wage index measured in units of consumption, $\tau_{t}^{c}$ and $\tau_{t}^{l}$ are the consumption and labor tax rates, $r m^{*}$ denotes remittances in units of foreign consumption (denoted by ${ }^{*}$ ), and $z_{t}$ denotes government transfers. $s_{t}$ is the CPI-based real exchange rate, and $\Omega_{t}^{T}$ and $\Omega_{t}^{N}$ are profits from the traded and nontraded good sectors, respectively. The household holds domestic government bonds $b_{t}$, which pay $R_{t} b_{t}$ units of composite consumption at $t+1$, with $R_{t}$ representing the domestic gross real interest rate. Throughout the analysis, we assume that government does not issue additional debt to finance public investment spending $\left(b_{t}=b \forall t\right)$. Households do not have access to foreign loans. ${ }^{10}$

\footnotetext{
${ }^{8}$ Low-income countries with IMF-supported programs are subject to debt limit policies on nonconcessional borrowing (International Monetary Fund, 2009). Even if nonconcessional borrowing can be feasible for some countries, it is subject to a high risk premium, which implies an almost closed capital account from a borrowing perspective. Concessional borrowing is possible - and the model can account for it as aid - although this is to a great extent beyond the authorities' control and exogenously given.

${ }^{9}$ See Appendix 1 in International Monetary Fund (2012c) for a list of resource-rich developing countries, and International Monetary Fund (2012a) for a survey of financial development in low-income countries.

${ }^{10} \mathrm{~A}$ typical low-income country features a large share of hand-to-mouth households, who do not have access to capital and asset markets and consume all their disposable income each period. Because of the assumptions that (1) the private sector faces a closed capital account, (2) firms (not households) own private capital, and (3) the government does not issue additional debt to finance public investment, the forward-looking households behave very similarly to the hand-to-mouth in response to shocks.
} 
Consumption $c_{t}$ is a composite of nontraded goods $\left(c_{t}^{N}\right)$ and traded goods $\left(c_{t}^{T}\right)$, combined in a constant-elasticity-of-substitution (CES) basket

$$
c_{t}=\left[\varphi^{\frac{1}{\chi}}\left(c_{t}^{N}\right)^{\frac{\chi-1}{\chi}}+(1-\varphi)^{\frac{1}{\chi}}\left(c_{t}^{T}\right)^{\frac{\chi-1}{\chi}}\right]^{\frac{\chi}{\chi-1}},
$$

where $\chi$ denotes the intratemporal elasticity of substitution, and $\varphi$ indicates the degree of consumption home bias. Let the composite consumption be the numeraire of the economy, and assume the law of one price holds for traded goods. Then, $s_{t}$ is also the relative price of traded goods to composite consumption. The CES basket implies that the price of one unit of composite consumption is

$$
1=\varphi\left(p_{t}^{N}\right)^{1-\chi}+(1-\varphi)\left(s_{t}\right)^{1-\chi}
$$

where $p_{t}^{N}$ is the relative price of nontraded goods to composite consumption.

\section{Aggregate Labor and Wage Rates}

Households only supply labor $l_{t}^{N}$ and $l_{t}^{T}$ to nonresource sectors. There is imperfect labor mobility as reflected by the following CES aggregator for total labor:

$$
l_{t}=\left[\delta^{-\frac{1}{\rho}}\left(l_{t}^{N}\right)^{\frac{1+\rho}{\rho}}+(1-\delta)^{-\frac{1}{\rho}}\left(l_{t}^{T}\right)^{\frac{1+\rho}{\rho}}\right]^{\frac{\rho}{1+\rho}}
$$

where $\delta$ is the share of labor in the nontraded sector in the initial steady state, and $\rho>0$ governs labor sectoral mobility. The real aggregate wage rate is then given by

$$
w_{t}=\left[\delta\left(w_{t}^{N}\right)^{1+\rho}+(1-\delta)\left(w_{t}^{T}\right)^{1+\rho}\right]^{\frac{1}{1+\rho}}
$$

\section{Firms}

Firms produce goods in either the nontraded goods sector $(N)$ or the traded goods sector $(T)$, using labor $(l)$, private capital $(k)$, and public capital $\left(K^{G}\right)$. The production in the natural resource sector $(O)$ is assumed to be exogenous, for simplicity.

\section{Natural Resource Sector}

Since most natural resource production in reality is capital intensive, and much resource investment in low-income countries is financed by 
FDI, we assume the following exogenous process for natural resource output:

$$
\frac{y_{t}^{O}}{y^{O}}=\left(\frac{y_{t-1}^{O}}{y^{O}}\right)^{\rho_{y o}} e^{\varepsilon_{t}^{y o}},
$$

where $\rho_{y o} \leqslant 1, \varepsilon_{t}^{y o} \sim$ i.i.d.N $\left(0, \sigma_{y o}^{2}\right)$ is the resource production shock and a variable without a time subscript is a variable's value at the initial steady state. We also assume that a country's resource output is relatively small in the world market, and that the international commodity price $p_{t}^{O *}$ (relative to foreign goods) is exogenous, following the process

$$
\frac{p_{t}^{O *}}{p^{O *}}=\left(\frac{p_{t-1}^{O *}}{p^{O *}}\right)^{\rho_{p o}} e^{\varepsilon_{t}^{p o}},
$$

where $\rho_{p o} \leqslant 1, \varepsilon_{t}^{p o} \sim$ i.i.d. $N\left(0, \sigma_{p o}^{2}\right)$ is the resource price shock. Resource GDP in units of domestic composite consumption is ${ }^{11}$

$$
Y_{t}^{O}=s_{t} p_{t}^{O *} y_{t}^{O}
$$

Resource production is subject to a royalty at a rate of $\tau^{o} .^{12}$ Resource revenue collected each period is

$$
T_{t}^{O}=s_{t} \underbrace{\left(\tau^{o} p_{t}^{O *} y_{t}^{O}\right)}_{\equiv T_{t}^{O *}} .
$$

As most resource output in developing countries is exported, ${ }^{13}$ we assume that resource output in the model is not consumed domestically.

\section{Nontraded Good Sector}

The nontraded sector is perfectly competitive. A representative firm uses the technology

$$
y_{t}^{N}=z^{N}\left(k_{t-1}^{N}\right)^{1-\alpha^{N}}\left(l_{t}^{N}\right)^{\alpha^{N}}\left(K_{t-1}^{G}\right)^{\alpha^{G}},
$$

\footnotetext{
${ }^{11}$ One way to further simplify the specification is to model the effects of a natural resource sector as foreign transfers that capture resource revenue flows (see, for example, Dagher, Gottschalk, and Portillo, 2012). By making explicit the natural resource GDP, however, the model can be calibrated to better match countries national accounts and fiscal data.

${ }^{12}$ In practice, other instruments or mechanisms, including production sharing contracts, corporate income taxes, and state ownership or participation, may also be used to collect resource revenue (International Monetary Fund, 2012b). Since our analysis concerns only total resource revenue collected, we use one instrument to calibrate the share of resource revenue in total revenue.

${ }^{13}$ For example, in the CEMAC region, Equatorial Guinea and Gabon have exported, respectively, almost 100 and 90 percent of their oil production. In recent years, Angola has also exported, at least 80 percent of oil output (Energy Information Administration, 2012).
} 
where $\alpha^{G}$ is the output elasticity with respect to public capital, and $z^{N}$ is a productivity scale parameter. ${ }^{14}$

Private capital evolves by the law of motion

$$
k_{t}^{N}=\left(1-\delta^{N}\right) k_{t-1}^{N}+\left[1-\frac{\kappa}{2}\left(\frac{i_{t}^{N}}{i_{t-1}^{N}}-1\right)^{2}\right] i_{t}^{N},
$$

where $\kappa \geqslant 0$ is the investment adjustment cost parameter.

A representative nontraded good firm maximizes its net present-value profit weighted by the marginal utility of households $\left(\lambda_{t}\right)$,

$$
E_{t} \sum_{t=0}^{\infty} \beta^{t} \lambda_{t} \underbrace{\left[(1-\imath)\left(p_{t}^{N} y_{t}^{N}\right)-w_{t}^{N} l_{t}^{N}-i_{t}^{N}+\imath p_{t}^{N} Y_{t}^{N}\right]}_{\equiv \Omega_{t}^{N}, \text { profit of the non-traded good sector }},
$$

where 1 captures distortions in developing countries that discourage firms from investing and hiring further, and $Y_{t}^{N}$ denotes the aggregate output of nontraded goods. ${ }^{15}$ Implicitly, 1 acts like a distorting tax on firms but revenue collected remains in the private sector, as in practice. For simplicity, these taxes are rebated back to the firms (hence households) in a lump-sum fashion.

\section{Traded Good Sector}

The traded good sector is also perfectly competitive and produces by a similar technology to that in the nontraded sector

$$
y_{t}^{T}=z_{t}^{T}\left(k_{t-1}^{T}\right)^{1-\alpha^{T}}\left(l_{t}^{T}\right)^{\alpha^{T}}\left(K_{t-1}^{G}\right)^{\alpha_{G}} \text {. }
$$

The productivity $z_{t}^{T}$ is subject to learning-by-doing externalities, depending on the last period traded output :

$$
\ln z_{t}^{T}=\rho_{z T} \ln z_{t-1}^{T}+d \ln y_{t-1}^{T} .
$$

Investment in traded good sector $\left(i_{t}^{T}\right)$ accumulates to capital $\left(k_{t}^{T}\right)$ following Equation (12). Each firm maximizes its profits as non-traded firms (equation (13)), and the implicit taxes collected are $s_{t} Y_{t}^{T}$.

\footnotetext{
${ }^{14}$ Following neoclassical literature on models with public capital (for example, Baxter and King, 1993 and Kamps, 2004), constant returns to scale are assumed with respect to private production inputs and increasing returns to scale with respect to public capital. Relative to another specification with constant return to scale to all production factors, this specification has the advantage that $\alpha^{N}$ can be calibrated to match income shares of labor and private capital of an economy.

${ }^{15}$ One modeling restriction of $\mathrm{l}$ in our specification is that it is linked to the investment to GDP ratio in the initial steady state. If data for calibrating 1 are available, the investment to GDP ratio becomes endogenous in the model. In general, this implicit tax helps match the relatively low investment to GDP ratios observed in developing countries.
} 


\section{The Government}

Let capital letters denote the aggregate level of a variable (for example, $C_{t}$ is aggregate private consumption). The flow government budget constraint is

$$
\begin{aligned}
T_{t}^{O}+ & \underbrace{}_{\equiv T_{t}^{N O}{ }_{\text {,non-resource tax }}^{c} C_{t}+\tau_{t}^{l} w_{t} L_{t}}+s_{t} A^{*}+s_{t}\left(1+r^{*}\right) F_{t-1}^{*} \\
& =p_{t}^{g} G_{t}+Z_{t}+\left(R_{t}-1\right) B+s_{t} F_{t}^{*},
\end{aligned}
$$

where $F_{t}^{*}$ is the asset value of a resource fund earning a constant real interest rate $r^{*}, A^{*}$ is foreign aid, $G_{t}$ is government purchases with a relative price to composite consumption goods of $p_{t}^{g}$, and $Z_{t}$ is aggregate transfers to households.

\section{Investment Efficiency and Absorptive Capacity Constraints}

Government purchases consist of expenditures on government consumption $G_{t}^{C}$ and public investment $G_{t}^{I}$. We introduce effective public investment $\left(\tilde{G}_{t}^{I}\right)$, which differs from the expenditure concept $\left(G_{t}^{I}\right)$, by allowing in the model for potential investment inefficiencies and absorptive capacity constraints. As a result, the law of motion of public capital is given by

$$
K_{t}^{G}=\left(1-\delta_{t}^{G}\right) K_{t-1}^{G}+\underbrace{\varepsilon_{t}\left(G_{t}^{I}\right) \times G_{t}^{I}}_{\equiv \tilde{G}_{t}^{I}, \text { effective investment }},
$$

where $\delta_{t}^{G}$ is the time-varying depreciation rate of public capital, and $0<\varepsilon_{t}<1$ governs the efficiency of public investment. To capture the idea that lack of maintenance shortens the life of existing capital, we follow Rioja (2003) to model the depreciation rate as a decreasing function of investment expenditure $^{16}$ :

$$
\delta_{t}^{G}=\left\{\begin{array}{ll}
\delta^{G} \times \frac{\delta^{G} K^{G} t-1}{\tilde{G}_{t}^{I}} & \text { when } \tilde{\mathrm{G}}_{\mathrm{t}}^{\mathrm{I}}<\delta^{G} K_{t-1}^{G} \\
\delta^{G} & \text { when } \tilde{\mathrm{G}}_{t}^{I} \geq \delta^{G} K_{t-1}^{G}
\end{array}\right\} .
$$

Based on the nonparametric estimation results by Arestoff and Hurlin (2006), we assume that investment efficiency takes two values: it falls from $\varepsilon$ to $\bar{\varepsilon}$ when the expenditure level rises above a threshold $\bar{G}^{I}$. This captures the

\footnotetext{
${ }^{16}$ Rioja (2003) separates investment expenditures between those for new projects and those for maintenance, and the depreciation rate is correlated positively with private capital to capture the intensity of public capital usage and negatively with maintenance expenditures.
} 
idea of rising investment costs because of absorptive capacity constraints. ${ }^{17}$ Specifically,

$$
\varepsilon_{t}\left(G_{t}^{I}\right)=\left\{\begin{array}{ll}
\varepsilon & \text { when } \mathrm{G}_{t}^{I}<\bar{G}^{I} \\
\bar{\varepsilon} & \text { when } \mathrm{G}_{t}^{I} \geq \bar{G}^{I}
\end{array}\right\} .
$$

Like private consumption, government purchases are a CES basket that includes traded and nontraded goods,

$$
G_{t}=\left[v_{t}^{\frac{1}{\chi}}\left(G_{t}^{N}\right)^{\frac{\chi-1}{\chi}}+\left(1-v_{t}\right)^{\frac{1}{\chi}}\left(G_{t}^{T}\right)^{\frac{\chi-1}{\chi}}\right]^{\frac{\chi}{\chi-1}},
$$

where $v_{t}$ denotes the degree of home bias in government purchases. The relative price of government consumption to private consumption is

$$
p_{t}^{g}=\left[v_{t}\left(p_{t}^{N}\right)^{(1-\chi)}+\left(1-v_{t}\right)\left(s_{t}\right)^{1-\chi}\right]^{\frac{1}{1-\chi}} .
$$

Note that $v_{t}$ can be time-varying. In general, a large share of government purchases go to wage bills for paying public servants, implying a relatively high degree of home bias. Since our analysis focuses on allocating additional government spending to public investment, we allow the degree of home bias for additional government spending $\left(v_{g}\right)$ to be different from its steady-state value $(v)$.

\section{Fiscal Policy}

Define a resource windfall as a resource revenue that is above its original steady-state level, that is, $T_{t}^{O *}-T^{O *}$ in units of foreign goods. Policy specifications below describe the three approaches analyzed in the paper. A resource fund in each approach serves different purposes, and hence its evolution is governed by different rules.

- Saving in a Sovereign Wealth Fund (SWF). Under this approach, all the resource windfall is saved externally in an SWF. As spending the additional resource revenue is limited to the interest income of a resource fund $\left(r^{*} F_{t-1}^{*}\right.$ in equation (16)), then the fund evolves according to

$$
F_{t}^{*}=F_{t-1}^{*}+\left(T_{t}^{O *}-T^{O *}\right) .
$$

${ }^{17}$ Several other approaches exist to model absorptive capacity constraints. Buffie and others (2012) model this as increasing "prices" of public investment. van der Ploeg (2012) models this as an internal adjustment cost linked to the public investment management index (PIMI, Dabla-Norris and others, 2011). 
- The All-Investing Approach. Here the resource fund stays at its initial level each period $F_{t}^{*}=F^{*} \forall t$, while public investment expenditures follow the rule:

$$
G_{t}^{I}=G^{I}+\left(\frac{T_{t}^{O}}{p_{t}^{g}}-\frac{T^{O}}{p^{g}}\right) .
$$

- The Sustainable Investing Approach. Under this approach, a relatively stable scaling-up path of public investment is specified, commensurate with a country's profile of resource revenue, absorptive capacity, and a development objective. In the case of a short resource revenue horizon, a resource fund is often established for saving purposes. Under this circumstance, we assume that a fixed share $\phi$ of a resource windfall is saved in an SWF each period, which evolves by

$$
F_{t}^{*}=F_{t-1}^{*}+\phi\left(T_{t}^{O *}-T^{O *}\right) .
$$

In the case where a resource fund is built for the stabilization purpose, the saving rate is time-varying. The fund instead evolves by

$$
F_{t}^{*}=F_{t-1}^{*}+\left(T_{t}^{O *}-T^{O *}\right)-\left(\frac{p_{t}^{g} G_{t}}{s_{t}}-\frac{p^{g} G}{s}\right),
$$

which allows savings in the fund to be negative (withdrawing) when additional government purchases exceed a resource windfall.

Under all fiscal approaches considered, different fiscal instruments are allowed to clear the government budget constraint, including transfers and consumption or labor tax rates. Those that do not adjust are set to their initial steady-state levels.

\section{Some Market Clearing Conditions and Identities}

The market clearing condition for nontraded goods is

$$
Y_{t}^{N}=\left(p_{t}^{N}\right)^{-\chi}\left[\varphi\left(C_{t}+I_{t}^{N}+I_{t}^{T}\right)+v\left(p_{t}^{g}\right)^{\chi} G_{t}\right] .
$$

Lastly, the balance of payment condition is

$$
\begin{aligned}
& \left(C_{t}+I_{t}+p_{t}^{G} G_{t}\right)-Y_{t}-s_{t}\left(r^{*} F_{t-1}^{*}+R M^{*}\right) \\
& \quad=s_{t}\left[A^{*}-\left(F_{t}^{*}-F_{t-1}^{*}\right)\right],
\end{aligned}
$$

where $I_{t}=I_{t}^{N}+I_{t}^{T}$ is total private investment, and $Y_{t}=p_{t}^{N} Y_{t}^{N}+s_{t} Y^{T}+Y_{t}^{O}$ is real GDP.

\section{Equilibrium and Calibration}

The equilibrium system of the model consists of the private agents optimality conditions, the government budget constraint, fiscal policy, market clearing conditions, the balance of payment condition, and the exogenous processes 
Table 1. Baseline Parameter Calibration

\begin{tabular}{|c|c|c|c|}
\hline Parameters & CEMAC & Angola & Notes \\
\hline$\sigma$ & 2 & 2 & $\begin{array}{l}\text { Inverse of intertemporal elasticity of substitution for } \\
\text { consumption }\end{array}$ \\
\hline$\psi$ & 10 & 10 & Inverse of Frisch elasticity of labor supply \\
\hline$\varphi$ & 0.5 & 0.4 & Degree of home bias in private consumption \\
\hline$\chi$ & 0.44 & 0.44 & Elasticity of substitution between traded and nontraded sectors \\
\hline$\delta$ & 0.45 & 0.56 & Share of labor supplied to nontraded sector \\
\hline$\rho$ & 1 & 1 & Elasticity of substitution between the two types of labor \\
\hline$\beta$ & 0.91 & 0.91 & The discount factor \\
\hline$\alpha^{N}$ & 0.45 & 0.45 & Labor income share in nontraded sector \\
\hline$\alpha^{T}$ & 0.65 & 0.65 & Labor income share in traded sector \\
\hline$\alpha^{G}$ & 0.10 & 0.20 & Output elasticity of public capital \\
\hline$d, \rho_{Z T}$ & 0.1 & 0.1 & Learning-by-doing externalities \\
\hline 1 & 0.18 & 0.20 & Firms' production distortion parameter (model implied) \\
\hline$\kappa$ & 25 & 25 & Investment adjustment cost \\
\hline$\delta^{N}, \delta^{T}$ & 0.1 & 0.1 & Depreciation rate for $K^{N}, K^{T}$ \\
\hline$\delta^{G}$ & 0.08 & 0.07 & Depreciation rate for public capital \\
\hline$\varepsilon, \bar{\varepsilon}$ & $0.5,0.35$ & $0.5,0.35$ & Public investment efficiency \\
\hline$Y^{O} / G D P$ & 0.09 & 0.475 & Oil GDP/GDP \\
\hline$v$ & 0.6 & 0.4 & Home bias of government purchases \\
\hline$v_{g}$ & 0.5 & 0.2 & $\begin{array}{l}\text { Home bias of government purchases above the level in initial } \\
\text { state }\end{array}$ \\
\hline$\tau^{l}$ & 0.08 & 0.1 & Effective labor tax rates \\
\hline$\tau^{c}$ & 0.18 & 0.1 & Effective consumption tax rates \\
\hline$s^{B}$ & 0.116 & 0.347 & Debt-to-GDP ratio in initial state \\
\hline$G^{C} / G D P$ & 0.133 & 0.195 & GC/GDP in initial state \\
\hline$G^{I} / G D P$ & 0.068 & 0.087 & GI/GDP in initial state \\
\hline$F^{*} / G D P$ & 0.01 & 0.02 & Stabilization fund/GDP in initial state \\
\hline$r^{*}$ & 0.027 & 0.027 & Annual real return to a resource fund \\
\hline$\rho_{y o}$ & 0.9 & 0.9 & AR(1) coefficient in oil production quantity \\
\hline
\end{tabular}

of the shocks. ${ }^{18}$ The model is at the annual frequency and applied to the CEMAC region and Angola, as representative cases of the policy challenges associated with natural resource revenue exhaustibility and volatility, respectively. Table 1 summarizes the baseline calibrations for each country. The two calibrations share many parameter values, especially those without country-specific estimates in the literature.

For both applications, we calibrate the degree of home bias in private consumption and investment to be $\varphi=0.5$, as in Burstein, Eichenbaum, and Rebelo (2005). For the elasticity of substitution between traded and nontraded goods, we set $\chi=0.44$, following Stockman and Tesar (1995). We use the estimate by Horvath (2000) for the labor mobility parameter: $\rho=1$. The risk aversion parameter for households is $\sigma=2-$ an intertemporal

${ }^{18}$ Optimality conditions and the equilibrium definition are available in the appendix of Berg and others (2012). 
elasticity of substitution of 0.5 - corresponding to the high end value of most estimates in developing countries (Agenor and Montiel, 1999). A low Frisch labor elasticity of $0.1(\psi=10)$ is assumed, in line with the $0.15-0.17$ wage elasticity of labor supply in rural Malawi (Goldberg, 2011). The discount factor $\beta=0.91$ corresponds to a domestic annual interest rate of 10 percent.

To calibrate the parameters related to absorptive capacity, we resort to the only direct empirical evidence we could locate in the literature. ${ }^{19}$ Using Mexican data from 1980 to 1994, Arestoff and Hurlin (2006) find that the coefficient of regressing public capital produced (or effective investment in our model) on investment expenditures falls from 0.5 to 0.35 when investment expenditures exceed 1.6 times of the average level in the sample. ${ }^{20}$ Thus, to calibrate Equation(19), we set $\varepsilon=0.5$ and $\bar{\varepsilon}=0.35$, and $\bar{G}^{I}=1.6 G^{I}$. This range of investment efficiency $(0.35-0.5)$ is in line with Pritchett's (2000) estimate for sub-Saharan countries with a linear specification between effective investment and investment expenditures.

For private production, data on factor shares in sub-Saharan Africa suggest that the capital share in nonresource production is about $0.55-0.6$ in the nontraded good sector and $0.35-0.4$ in the traded good sector. ${ }^{21}$ According to the low end of these ranges, then the sectoral labor income shares are $\alpha^{N}=0.45$ and $\alpha^{T}=0.65$. Both applications set the depreciation rates for private capital to be at 10 percent in nontraded and traded sectors $\left(\delta^{N}=\delta^{T}=0.1\right)$. Without empirical backing, we assume a minor degree for the learning-by-doing externality: $\rho_{z T}=d=0.1$. The parameter of investment adjustment costs is set to $\kappa=25$, following the calibration in Berg and others (2010).

Resource production shocks are assumed to be somewhat persistent: $\rho_{y o}=0.9$ in (7). Since the resource commodity in both applications is oil, we assume that the real oil price follows a random walk without a drift $\left(\rho_{p o}=1\right.$ in equation (8)) as estimated by Hamilton (2009). The oil price per barrel in the initial steady state is set to $\$ 94$ a barrel, matching the 2011 actual average and the WEO price forecast (World Economic Outlook database updated June 2012, International Monetary Fund, 2012e) from 2012 to 2017. Based on the average real return of the Norwegian Government Pension Fund from 1997 to 2011 (Gros and Mayer, 2012), the annual real return of a resource fund is set to 2.7 percent $\left(r^{*}=0.027\right)$.

\footnotetext{
${ }^{19}$ Absorptive capacity constraints in developing countries have long been recognized (for example, Horvat, 1958; Adler, 1965; Chenery and Strout, 1966; and Berg, 1983), but direct empirical evidence is scant. Shi (2012) finds indirect evidence: When implementing the Western Development Project in West China, the growth effect of investment declined as investment accelerated.

${ }^{20}$ Arestoff and Hurlin (2006) also provide estimates for Colombia. Although the average slope is similar to that of Mexico about 0.4, the relationship appears to be linear regardless of investment levels. This suggests that experience on absorptive capacity constraints is likely to vary across countries.

${ }^{21}$ See the GTAP5 database, assembled by the Global Trade Analysis Project and the International Food Policy Research Institute. See Buffie and others (2012) for a summary of other estimates for factor shares of countries in sub-Saharan Africa.
} 
The rest of the section describes the country-specific parameterization to match the national accounts and fiscal data in the calibrated initial steady state of each economy.

\section{The CEMAC Region}

Oil production in the CEMAC region reached its peak in mid-2000 at about 400 million barrels a year. By 2010, it had declined to 376.8 million barrels or 37 percent of CEMAC GDP (Caceres, Poplawksi-Ribeiro, and Tartari, 2011). Based on projections by IMF country teams, oil production is projected to gradually decrease and reach a low level of about 100 million barrels in 2030 (roughly the production level in 1980). We calibrate the initial steady state to have a low level of oil production, about 9 percent of GDP. While the oil production remains high in the starting year of the simulations (2012), the region is on its way to this low level of oil production, making explicit exhaustibility concerns. ${ }^{22}$

The initial steady state is calibrated to match averages of WEO historical data, subject to availability. The trade balance is set to 5.7 percent of GDP based on the average of exports and imports from 1980 to 2000. For private investment, the 1990-2010 average historical share of GDP is 0.17 . Together with a 10 percent depreciation rate of private capital, the model implies a distorting factor of $1=0.16$. Government expenditure is set to equal the 2000-10 average of 20.1 percent of GDP, out of which 6.8 percent is public investment.

As for the return to public capital, a wide range of estimates exists in the literature. Bai and Qian (2010) estimate the return to various types of infrastructure in China and obtain a rate of around 10 percent for transport, storage, and postal service in the early 1980s, and also around 10 percent for railway systems in the early 1990s. Estimates for investment projects in lowincome countries are diverse and changing over time. The median return of the World Bank projects increased from 12 percent in late 1989s to 24 percent in 2008 (International Bank for Reconstruction and Development and the World Bank, 2010). Based on a large project-level disbursement data set, Kraay (2012), however, finds that World Bank projects have small output multipliers in low-income countries. Our baseline calibration for the CEMAC region assumes the elasticity of public capital to output is $\alpha^{G}=0.1$. Together with an annual depreciation rate of public capital of 8 percent $\left(\delta^{G}=0.08\right)$, this implies an annual return to public capital-defined as marginal product of public capital less depreciation - of 13.4 percent. $^{23}$

\footnotetext{
${ }^{22}$ Following the DSGE convention, the starting point of the simulation is a steady state. For developed economies, this steady state is often a balanced growth path that characterizes the long-term average performance of an economy. For developing countries analyzed here, we calibrate this steady state to be an initial state that characterizes the average past performance of the economy.

${ }^{23}$ Our calibrated depreciation rate is much higher than the range of 2.5-4.3 percent used for developing countries in the literature (for example, Hurlin and Arestoff, 2010 and Gupta
} 
The implied public capital is 42.5 percent of GDP in the initial steady state, roughly the average estimated ratio of public capital to GDP of developing countries in 2003 (based on a sample of 31 developing countries estimated by Cubas, 2011). Because the return to public investment plays an important role in our analysis, we explore the implication of varying $\alpha^{G}$ from 0.05 to 0.2 for the CEMAC simulations.

Based on International Monetary Fund (2011), the average VAT rate for the CEMAC countries is about 18 percent $\left(\tau^{c}=0.18\right)$. To target the average ratio of tax revenue to GDP ratio at 0.18 from 1990 to 2010 , the labor tax rate $\tau^{l}=0.08$. When calibrating the oil tax rate, we set $\tau^{o}=0.58$ to match an initial oil revenue share in total revenue of 0.55 , roughly the average share from 2000 to 2010. Based on the 1980-2000 average of the government balance, a low level of a resource fund at 1 percent of GDP is assumed in the initial state. Also, the average external debt to GDP ratio of the CEMAC region at the end of 2010 implies that public debt at the initial steady state is 11.6 percent of GDP.

Lastly, without empirical support, we assume that the degree of home bias in government purchases has a higher content in nontraded goods, $v=0.6$. For government purchases financed by a resource windfall, the degree of home bias falls to $0.5\left(v_{g}=0.5\right)$, as increased public investment spending is more likely to fall on traded goods.

\section{Angola}

For the Angola simulations, the initial steady state is mostly calibrated based on the data of 2011, following Richmond, Yackovlev, and Yang (2012). The oil production in the initial state is set to the 2011 level of 606 million barrels and oil output is 47.5 percent of GDP. Given an oil tax rate of 0.58 , the model implies that oil tax receipts are about 80 percent of total government revenue. ${ }^{24}$ Since Angola has not saved abroad its oil revenue, the size of the stabilization fund in the initial state is set at a low value of 2 percent of GDP.

Given a high dependence on oil production, Angola has relied on imports to a large extent to meet domestic demand. For private consumption and investment baskets, we assume $\varphi=0.4$, less than the typical value of 0.5 . Moreover, the degree of home bias in government purchases is $v=0.4$ in the initial steady state. For additional government spending above the steadystate level, the degree of home bias is assumed to be even lower as reflected by $v_{g}=0.2$. Since oil production is almost 50 percent of GDP, the assumption of unusually low degree of home bias is consistent with a rather small

and others, 2011). Since lack of maintenance on public capital is common in low-income countries (World Bank, 1994), the actual depreciation rate in the CEMAC region is likely to be higher than the typically assumed low rate.

${ }^{24}$ The oil tax rate in Angola is oil price dependent in the model, as in practice: $\tau_{t}^{o}=0.56$ if the crude oil per barrel is less than U.S. $\$ 75 ; \tau_{t}{ }^{\circ}=0.58$ if between U.S.\$75 and U.S.\$100; $\tau_{t}{ }^{o}=0.6$ if between U.S. $\$ 100$ and U.S. $\$ 125$; and finally, $\tau_{t}{ }^{o}=0.65$ if the oil price is above U.S.\$125. 
nonresource production sector; the model implies that nonoil traded good production is only 17 percent of GDP.

Public investment in the initial steady state is 8.7 percent of GDP, the 2011 level. Given a 7 percent depreciation rate and investment efficiency of $\varepsilon=0.5$, we choose $\alpha^{G}=0.2$ to target a return to public capital of 10 percent. Government consumption is 19.5 percent of GDP, and debt is 34.5 percent of GDP in the initial state. Without specific tax rate data, consumption and labor tax rates are both set at 0.1 , implying that the nonresource tax revenue is about 20 percent of total revenue. The model implied implicit tax rate is $\imath=0.2$.

Finally, because our focus here is on the implications of natural revenue volatility, Angola simulations are conducted under stochastic oil prices. To calibrate the standard deviation of oil price shocks, the process of Equation (8) with $\rho_{p o}=1$ is estimated using (log) real oil price data from 1980 to 2011. This yields $\sigma^{p o}=0.1 .^{25}$

\section{Investing with a Short Revenue Horizon}

The analysis begins by showing how the model and sustainable investing approach can be used to inform policy decisions when a resource horizon is short. The conventional PIH advice - to save in an SWF-may be attractive when resource revenues are expected to be exhausted within 20 years. By comparing the macroeconomic outcomes under the approaches of saving in an SWF vs. investing in public capital, we show that absorptive capacity, return to public capital, and financing costs of sustaining capital are important factors to consider. Also, we simulate the effects of investment scaling-up financed by nonresource taxes. The inefficiency and the resulted high economic costs in taxing nonresource production highlight the important role of resource windfalls for economic development in developing countries.

\section{Saving in an SWF vs. Investing in Public Capital}

The simulation for the CEMAC region takes as given the oil production from 2012 to 2030 by IMF country teams. Since the current oil production is much above the level in the steady state, the model is solved by a nonlinear perfect foresight solution to avoid approximation errors due to linearization. ${ }^{26}$

Figure 1 presents the responses of four scenarios under the two approaches to managing oil revenue in the CEMAC region. Oil production, held at the same levels across all scenarios, is expected to decline from about 380 million barrels a year in 2012 to 100 million barrels in 2030. The solid lines are with

\footnotetext{
${ }^{25}$ The oil price series is the simple average of three spot prices: Dated Brent, West Texas Intermediate, and Dubai Fateh.

${ }^{26}$ The constant oil price assumption and the perfect foresight solution ignore the role of volatility and uncertainty played in policy decisions, which will be studied in Section IV, conducting stochastic simulations for the Angola application.
} 
Figure 1. CEMAC Application: Saving in an SWF (solid lines) vs. All-Investing (Dotted-Dashed Lines)

oil quantity ( $\mathrm{m}$ of barrels)
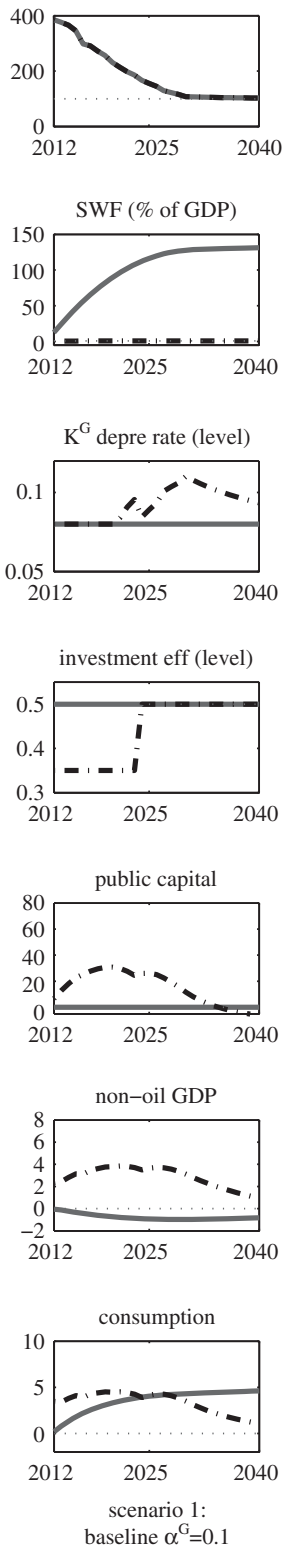

oil quantity ( $\mathrm{m}$ of barrels)
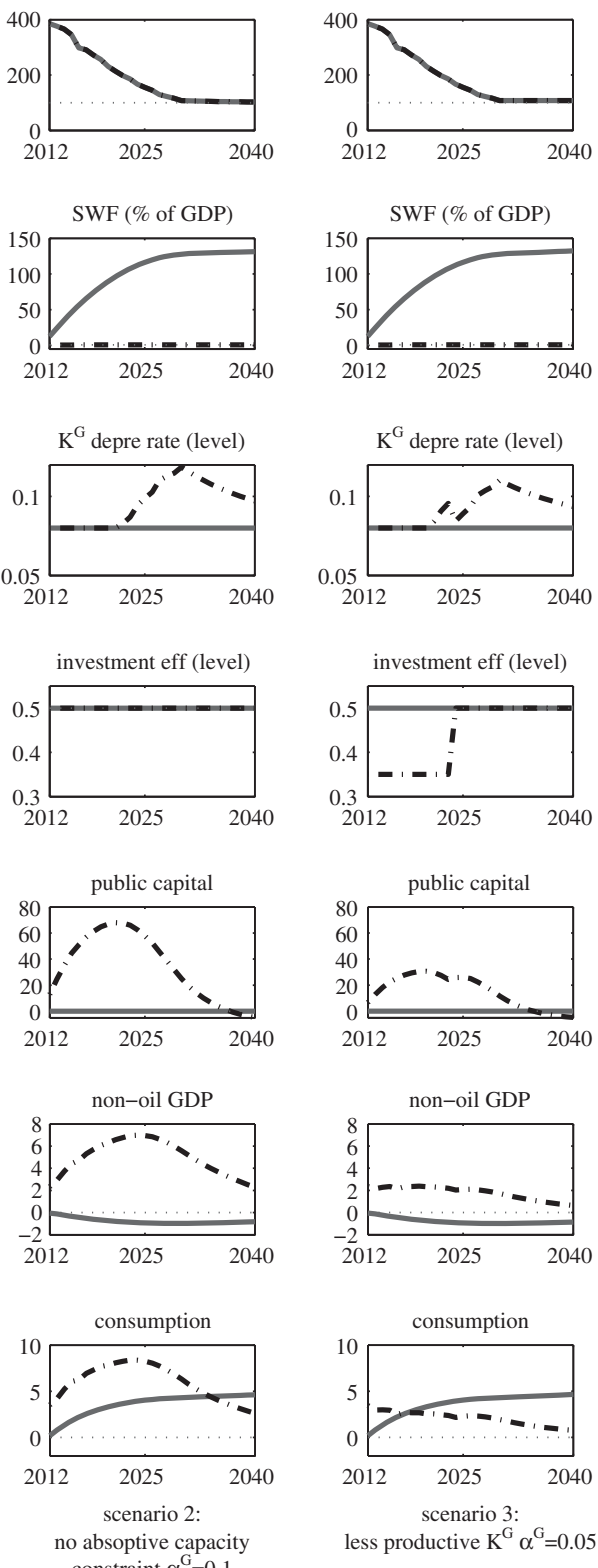

oil quantity ( $\mathrm{m}$ of barrels)

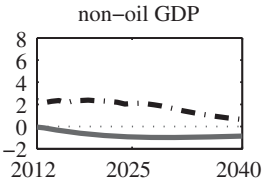

oil quantity ( $\mathrm{m}$ of barrels)
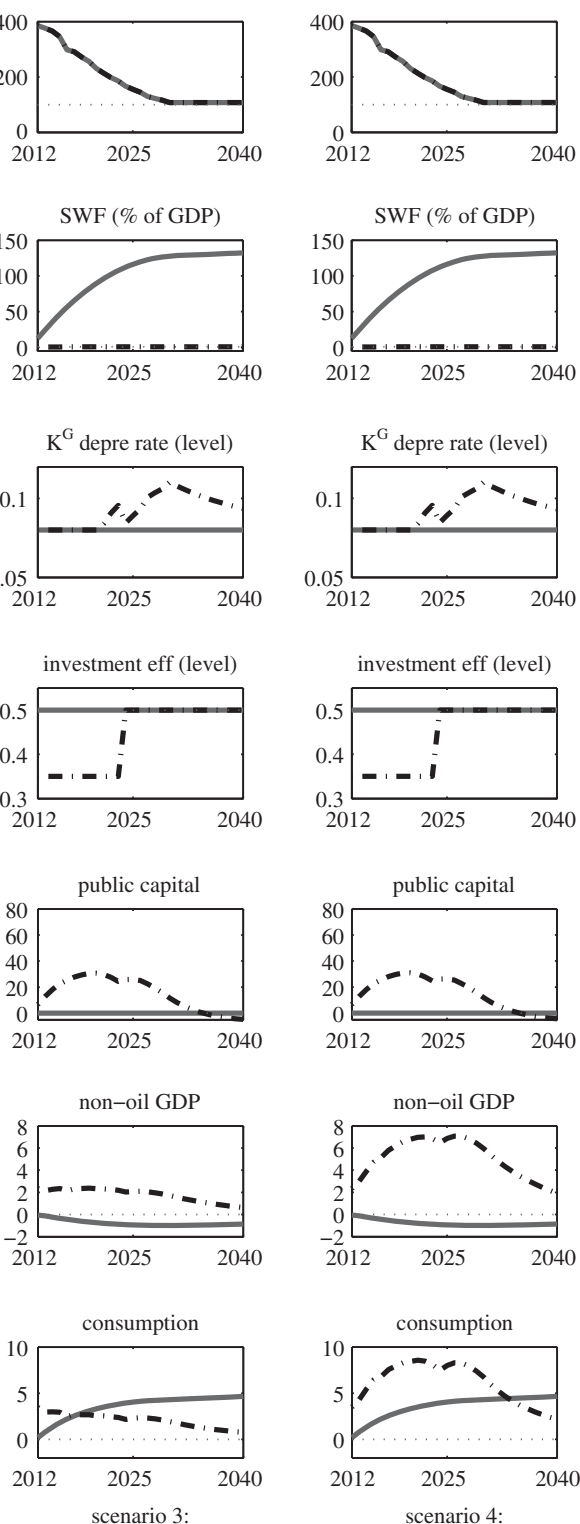

less productive $\mathrm{K}^{\mathrm{G}} \alpha^{\mathrm{G}}=0.05$

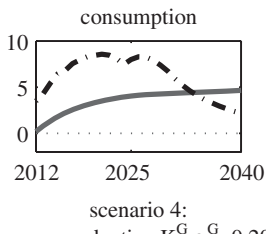

more productive $\mathrm{K}^{\mathrm{G}} \alpha^{\mathrm{G}}=0.20$

$\mathrm{Y}$-axis is in percent deviation from the path without a windfall unless stated otherwise. 
saving in an SWF, and the dotted-dashed lines are with the all-investing approach. Unless indicated in parentheses, the units are in percent deviations from a growth path in absence of oil windfalls from the level in the initial steady state.

\section{The Baseline Scenario}

The first column presents the results under the baseline calibration (Table 1). With saving in an SWF, accumulation of windfall revenue (by equation (22)) increases the fund steadily, reaching 132 percent of GDP in the new steady state. The interest income from the SWF enters the regular budget each period and is mainly distributed to households as transfers. ${ }^{27}$ As transfers increase, private consumption becomes higher. Despite a temporary windfall, households enjoy a permanent higher level of consumption because of a higher net foreign asset position. In the new steady state, consumption is 5.2 percent higher relative to the path without the windfall. With higher consumption, the wealth effect has a small negative influence on labor inputs. ${ }^{28}$ Consequently, non-oil GDP experiences a small decline in the new steady state. Public capital does not increase because public investment stays constant at the initial steady state level.

In contrast to saving in an SWF, the all-investing approach invests all the windfall in public capital (equation (23)), building up a higher public capital stock. At the peak (in 2025), public capital is 26 percent higher relative to the path without the windfall. Higher public capital raises the marginal product of private inputs, resulting in higher non-oil GDP. But higher output also means more income to households, which supports higher private consumption. At the peak (in 2026), consumption is 4.3 percent above the path without the windfall and slightly higher than consumption with saving in an SWF (4.1 percent). Consequently, welfare is also higher under allinvesting by 1.0 percent of initial steady-state consumption each period. ${ }^{29}$

\footnotetext{
${ }^{27}$ The results are similar when the interest income is used to lower the consumption tax rate.

${ }^{28}$ Given our calibration of a low Frisch labor elasticity $(0.1)$, the influence of negative labor responses on nonresource output is suppressed. An alternative modeling strategy is to adopt the Greenwood-Hercowitz-Huffmann preference (Greenwood, Hercowitz, and Huffmann, 1988), which removes the wealth effect. A number of researchers, however, find a negative effect of remittance income on labor supply in developing countries, suggesting some wealth effect still operates; see, for example, Kim (2007).

${ }^{29}$ The welfare is measured by the average consumption change each period - in percent of consumption of the initial steady state - required to equate the present-value welfare in a path with a windfall to that in a path without. The horizon computed is from 2012 to 2040. A high discount factor (more impatient households) would mean that saving in an SWF-which has higher consumption later-has a higher chance to be preferred than all-investing, holding everything else constant.
} 


\section{Absorptive Capacity}

Absorptive capacity constraints are a fundamental factor for the benefits of investing oil windfalls. The first column of Figure 1 shows that despite much more public investment, households only enjoy slightly more consumption with all-investing than with saving in an SWF. This is because the baseline assumes that absorptive capacity constraints are binding; investment efficiency falls from 0.5 to 0.35 before 2025 . The second column explores the scenario where absorptive capacity constraint does not bind: $\varepsilon=0.5 \forall t$. Relative to column one, public capital under all-investing rises much higher with the same amount of investment expenditures as the baseline. Consequently, non-oil GDP and private consumption are much higher. Peak consumption in scenario 2 is 8.4 percent higher than under the path without a windfall, compared with 4.3 percent with binding constraints. Between saving in an SWF and all-investing in scenario 2, on average households enjoy more utility each period relative to saving in an SWF, equal to 3 percent of consumption in the initial steady state.

Our model assumes that investment efficiency does not improve over time, because generally its underlying factors, such as institutional and governance quality as well as administration and managing capacity, can take a long time to improve. If public investment can be devoted to investing in building up capacity in implementing good investment ("investing in investing" in the terminology by Collier, 2009), the model could be revised to have investment efficiency changing along with investment expenditures in capacity building.

\section{Return to Public Capital}

In addition to absorptive capacity, another important factor for saving and investing decisions is the return to public capital. In light of a wide variation among public investment projects, the rest two scenarios explore different values for $\alpha^{G}$. Scenario 3 (the third column) assumes $\alpha^{G}=0.05$, implying an annual return of 2.7 percent, compared with 13.4 percent in the first two columns. Scenario 4 (the last column) has $\alpha^{G}=0.20$ or an annual return of 35 percent, much higher than the median return (24 percent) of World Bank projects in 2008 (International Bank for Reconstruction and Development and the World Bank, 2010).

When investment projects are almost unproductive as in scenario 3, households are better off saving in an SWF. They enjoy much more consumption throughout most of the horizon relative to the case with allinvesting. By the end of 2040, private consumption under saving in an SWF is 4.7 percent above the path without the windfall, while it is only 0.8 percent with all-investing. If instead public investment is quite productive as in scenario 4, households enjoy more consumption before 2035 with allinvesting than with saving in an SWF. The welfare with all-investing on average is 3.2 percent higher than with saving in an SWF. Summarizing, the scenarios presented in the last two columns of Figure 1 highlight the 
sensitivity of economic outcomes to returns to public capital. While investing a windfall can build much needed public capital for development, when public capital is not sufficiently productive, an economy is better off following the conventional advice to save a windfall in an external fund. ${ }^{30}$

\section{Sustaining Public Capital}

A frequently ignored issue by the literature that promotes public investment is that, when a resource revenue horizon is short, sustaining public capital built with a windfall may be difficult in the long run. In reality, it is often the case that politicians have preference to new projects instead than allocating budget for operating and maintaining existing capital. ${ }^{31}$ This section discusses the financing issue of sustaining public capital under a short revenue horizon. It also introduces the sustainable investing approach as an alternative to ensure long lasting development gains from investing a windfall.

\section{The Cost of Fiscal Adjustments}

With all-investing, one way to sustain capital after the windfall period is to make fiscal adjustments. Figure 2 presents the four scenarios (as in Figure 1) with all-investing but assumes that transfers to households (solid lines) or the consumption tax rate (dotted-dashed lines) are adjusted to sustain public capital. Across scenarios, Figure 2 shows that some fiscal adjustments are required to sustain capital after a windfall ends. The argument that increases in nonresource revenue through more public capital ought to be sufficient to sustain capital does not prevail here; even scenario 4 (the high capital return) requires slight adjustment in the long run. In the baseline (first column), the transfers to GDP ratio has to be lowered to 0.9 percent of GDP in the new steady state, from 2.7 percent in the initial steady state. If financed by taxes, the consumption tax rate has to be raised to 0.21 in the new steady state, from 0.18 originally.

With higher public capital relative to the case without sustaining capital (dotted-dashed lines in the first column of Figure 1), non-oil GDP is also higher in the new steady state. Whether households can enjoy more consumption, however, depends on the relative strength of the benefit from more public capital and the cost of fiscal financing. Table 2 contains the welfare comparison results. Households on average enjoy slightly higher welfare when capital is sustained under scenarios 1 (the baseline) and 4 . When public capital is less productive (scenario 3), households are slightly better off if capital is not sustained, since the benefits from more capital

\footnotetext{
${ }^{30}$ Given our baseline calibration for the CEMAC region, the threshold value of $\alpha^{G}$ to yield the same welfare measure with savings in an SWF and all-investing is 0.054 .

${ }^{31}$ Heller (1979) documents many examples of lost productivity resulting from lack of funding to cover capital recurrent costs, for example, new schools without qualified teachers, pastoral wells falling into disrepair.
} 
Figure 2. CEMAC Application: All-Investing and Sustaining Public Capital by Fiscal Adjustments through Consumption Taxes or Transfers
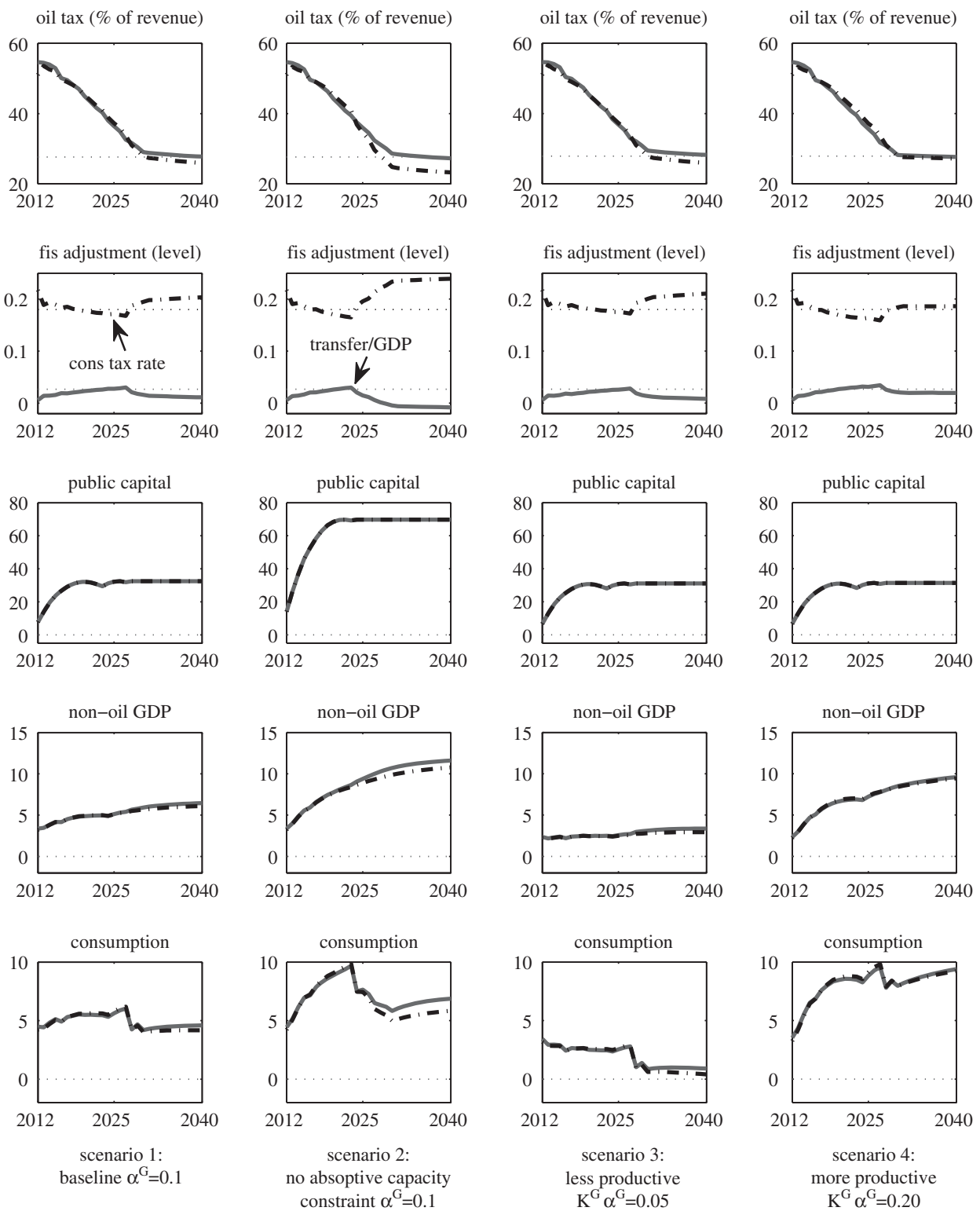

$\mathrm{Y}$-axis is in percent deviation from the path without a windfall unless stated otherwise.

is small. Similarly, households are also better off with unsustained capital in scenario 2. Since more capital is built with nonbinding absorptive capacity constraints, a higher investment level is required to maintain capital. Hence, fiscal adjustment magnitudes have to be a lot bigger. Transfers as a share of 
Table 2. Welfare Comparison with All-Investing

\begin{tabular}{lcccc}
\hline Scenarios & $\begin{array}{c}\text { Baseline } \\
\alpha^{G}=0.1\end{array}$ & $\begin{array}{c}\text { Scenario 2 } \\
\alpha^{G}=0.1, \varepsilon=0.5 \forall t\end{array}$ & $\begin{array}{c}\text { Scenario 3 } \\
\alpha^{G}=0.05\end{array}$ & $\begin{array}{c}\text { Scenario 4 } \\
\alpha^{G}=0.2\end{array}$ \\
\hline (1) Not sustaining $K^{G}$ & 3.36 & 6.42 & 2.28 & 5.59 \\
(2) Sustaining $K^{G}$, transfer adjusts & 4.50 & 6.13 & 2.18 & 6.06 \\
(3) Sustaining $K^{G}, \tau^{c}$ adjusts & 4.49 & 6.06 & 2.16 & 6.07 \\
\hline
\end{tabular}

See footnote 29 for the definition of welfare measure.

GDP now have to be lowered to -0.01 , equivalent to a lump-sum tax of 1 percent of GDP. Alternatively, the consumption tax rate has to be raised to 0.24 in the new steady state. Aside from their negative economic impact, these large adjustments might not be feasible in practice. Given the political economy constraints in implementing large fiscal adjustments, public capital stocks built with windfalls are likely to depreciate over time.

\section{The Sustainable Investing Approach}

One of the main challenges of investing a short-horizon resource windfall is to sustain capital in line with long-run fiscal sustainability. Instead of pursuing two extreme approaches of either saving abroad or investing all domestically, we propose the "sustainable investing approach" that combines these two approaches. The key to preserve resource wealth in the form of physical capital is to choose a sustainable scaling-up magnitude, given a windfall size and other fiscal and structural characteristics of the country. After a windfall is exhausted, interest income from any external savings and additional nonresource revenue can then jointly finance recurrent costs to maintain capital.

To formalize this approach, we specify an investment rule characterized by an initial increase in investment expenditure $G_{0}^{I}$, a scaling-up investment target in the new steady state $G_{n s s}^{I}$, and an investment speed of adjustment $\gamma$.

$$
G_{t}^{I}=\left(1-e^{-\gamma t}\right) G_{n s s}^{I}+e^{-\gamma t} G_{0}^{I} .
$$

When $\gamma=0, G_{t}^{I}=G_{0}^{I} \forall t$, and when $\gamma \rightarrow \infty, G_{t}^{I}=G_{n s s}^{I} \forall t$. Given a saving share $\phi$ of a windfall, the resource fund evolves by Equation (24). Since oil production is projected to decline over time, and the authorities may have an intention to speed up the investment scaling-up, we choose $G_{0}^{I}>G_{n s s}^{I}$, implying a front-loaded path for investment spending. Also, across all cases, we choose $\gamma=0.15$ to yield a gradual declining investment path, settling at a level sufficient to sustain capital. The simulations presented here assume that the consumption tax rate is the instrument of fiscal adjustment. The results are similar under transfers adjustment.

The solid lines of Figure 3 compare the three cases with different scalingup magnitudes and saving shares of a resource windfall under the baseline. For facility, the dotted-dashed lines repeat the outcomes of the all-investing 
Figure 3. CEMAC Application: Sustainable Investing Approach
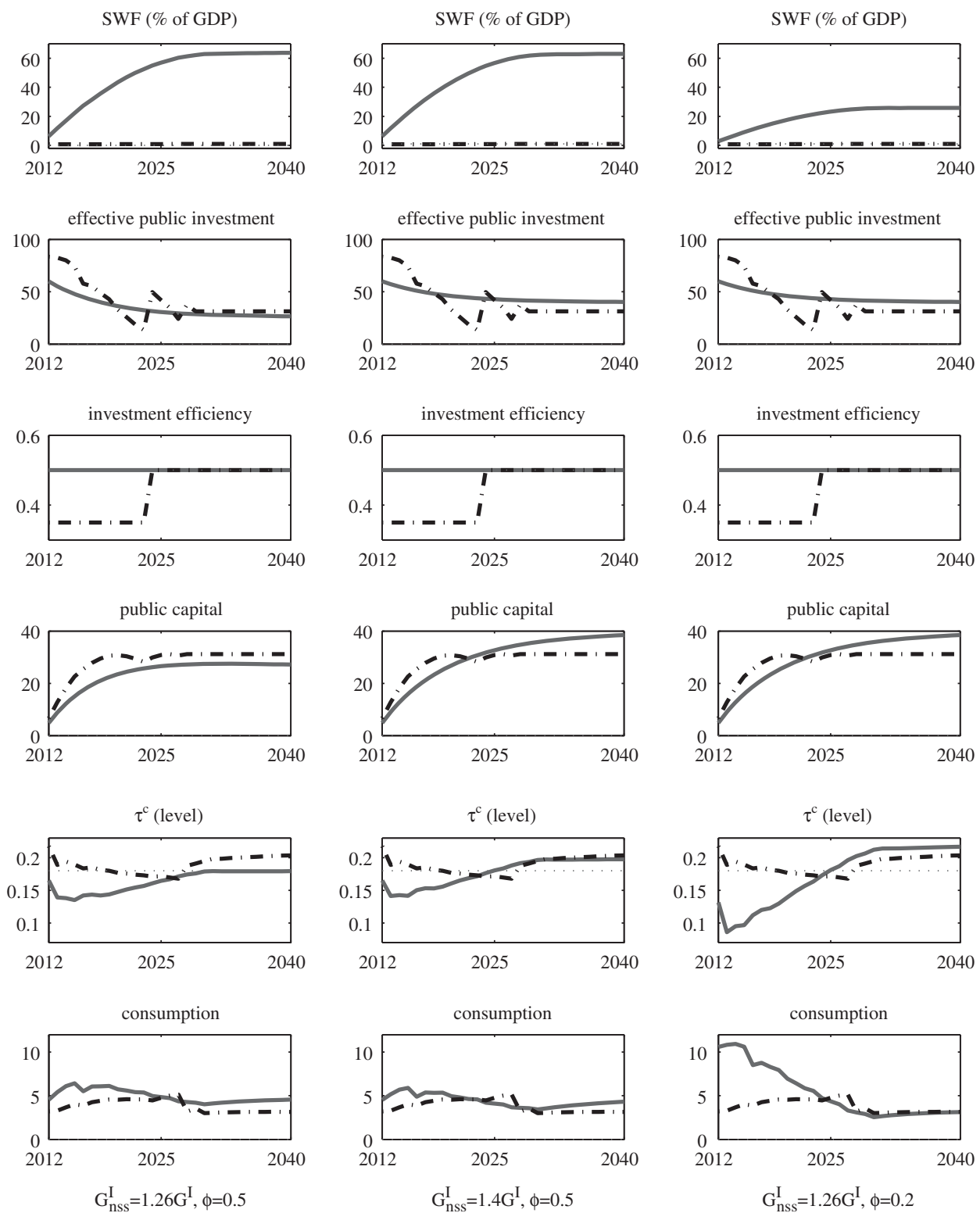

Y-axis is in percent deviation from the path without a windfall unless stated otherwise.

approach under the baseline, combined with raising the consumption tax rate to sustain capital. The first column has $G_{0}^{I}=1.6 \times G^{I}, G_{n s s}^{I}=1.26 \times G^{I}$, and $\phi=0.5$. Public capital is 26 percent permanently higher relative to the path without a windfall, and the resource fund climbs to 64 percent of GDP. Higher public capital leads to permanently higher nonresource GDP and 
private consumption. During the transition path, as external savings and additional public investment expenditure do not fully exhaust a resource windfall, the government is also able to lower the consumption tax rate, boosting private consumption during the windfall period. ${ }^{32}$

Compared with all-investing, public capital is scaled up at a slower pace and at a lower level with the sustainable investing approach. The moderate investment increase, however, implies that investment efficiency does not worsen. During the first 12 years, $\varepsilon$ stays at a constant level of 0.5 with sustainable investing, relative to 0.35 with all-investing. In addition, sustainable investing under the scaling-up magnitude of $1.26 \times G^{I}$ and the saving rate of 0.5 also remove the need for fiscal adjustments after the windfall is exhausted. The interest income from a resource fund finances part of the capital recurrent cost. In the new steady state, the consumption tax rate returns to its initial steady-state level. As a result, consumption is higher relative to that of all-investing, where the consumption tax rate has to be raised to 0.21 permanently. In welfare terms, households enjoy on average more periodic utility - equivalent to 1.1 percent of initial steady-state consumption - with sustainable investing than with all-investing.

To see the implications of a higher scaling-up, the second column assumes that investment in the long run is 40 percent higher than the initial steady-state level. While public capital is now higher at 38 percent (compared with 26 percent in column one), the interest income derived from the sovereign wealth fund becomes insufficient to support higher investment. To sustain capital, the consumption tax rate has to be raised to 0.2 . Despite more public capital and nonresource GDP, consumption is lower because of higher consumption tax rates. Periodic utility is on average 0.5 percent lower compared with the case of 26 percent scaling-up.

The last column presents the case of a lower saving rate $(\phi=0.2)$, while the scaling-up remains at 26 percent. The lower saving rate leads to a smaller resource fund. With the same scaling-up magnitude as column one, more resource windfall can be allocated to reduce the consumption tax rate, resulting in a consumption boom during the windfall period. After the windfall, a smaller resource fund yields less interest income, and the consumption tax rate has to be raised to about 0.2 to sustain capital. In the new steady state, private consumption is 1.7 percent lower than under the case with a 50 percent saving rate.

The results in Figure 3 illustrate how the framework can help determine a scaling-up magnitude given a projected windfall path. The choices of $G_{n s s}^{I}=1.26 \times G^{I}$ and $\phi=0.5$ in the first case are pinned down after a sequence of simulations to find the magnitude that does not require fiscal adjustment

\footnotetext{
${ }^{32}$ In practice, the government need not lower the consumption tax rate. It could save more of a resource windfall in a resource fund, distributes it to households as transfers, or even raise government consumption spending. The messages from changing all-investing to the sustainable investing approach remain valid regardless of these minor differences in policy design.
} 
in the long run. ${ }^{33}$ The results are certainly conditioned on assumptions about return to public capital, absorptive capacity constraints, and so on. When investment projects are less productive or the costs of absorptive capacity constraints are higher, fiscal adjustments would be larger and thus more difficult to implement. To avoid repeating the history that much of the public capital built under a windfall cannot have long-lasting growth effects, initial planning of an investment scaling-up must account for the future financing needs to sustain capital.

\section{Development without the Windfall}

The above discussion of financing costs of public investment sheds some light on a fundamental question related to the Lucas paradox (Lucas, 1990 and Gourinchas and Jeanne, forthcoming): Why is that in a capital-scarce economy, a public investment scaling-up cannot occur in the absence of a resource windfall? In our setup, part of the answer is the closed capital account reflecting tight borrowing constraints: Foreign capital does not flow easily to finance development. This assumption is common in most of the literature and largely consistent with stylized facts (see UNCTAD, 2012). The country in our model, however, is implicitly able to develop the natural resource sector through FDI. In practice, and despite borrowing constraints, this is feasible since there are substantial rents from resource extraction that foreigners can appropriate. These rents then make the extractive industry foreign investment attractive even in the face of the usual barriers to international capital flows related to sovereign immunity and poor governance in recipient countries. ${ }^{34}$

One may still wonder why a properly motivated government would not finance high-yielding public investments through its own revenue effort. A variety of distortions - some playing a role in the model presented here and many not - can explain why this typically has not happened. We emphasize two. One is again the financing constraint and closed capital account, which implies that to finance the scaling-up, countries would need to go through drastic fiscal adjustments and, therefore, possible substantial reductions in private consumption and investment. Second is the weak and distortionary domestic tax system (captured here by low effective tax rates and the ineffectiveness of the income tax). ${ }^{35}$

\footnotetext{
${ }^{33}$ The analysis does not suggest that a scaling-up magnitude that requires fiscal adjustment later is necessarily inferior to the one that does not. It depends on the feasibility of fiscal adjustments in a country, as well as on the distorting effect of such adjustments. From the perspective of preserving resource wealth with physical assets, choosing a sustainable scaling-up magnitude, however, is desirable.

${ }^{34}$ For example, the greatest FDI flows to sub-Saharan Africa in 2011 went to Nigeria, Ghana, Congo, Mozambique, and Zambia and were to a very large extent directed at natural resource extraction (UNCTAD, 2012).

${ }^{35}$ Our model makes explicit the fiscal challenges regarding tax revenue mobilization in developing economies. Despite taxing revenues from the nontraded and traded sectors
} 
To see the role of a resource windfall in facilitating development, Figure 4 compares two scaling-up scenarios. The dashed lines repeat the sustainable investing case in the first column of Figure 3, which has a frontloaded investment path with a 26 percent scaling-up. The solid lines undertake the same scaling-up path, but the economy does not experience any oil windfall. The dotted-dashed lines also assume no resource windfall but take a more gradual scaling-up path, reaching the same level in the new steady state.

As expected, when scaling up without a windfall, the consumption tax rate has to adjust substantially. In particular, when public investment is front-loaded (solid lines), the consumption tax rate has to jump drastically from 0.18 to almost 0.27 immediately implying a substantial fall in private consumption. In the gradual scaling-up case (dotted-dashed lines), private consumption does not fall as much, but the consumption increase in the new steady state is still minimal. Without a windfall, welfare is higher if the scaling-up is not undertaken. In contrast, with the windfall, welfare is generally higher under either scaling-up approach (all-investing or sustainable investing) than with full saving of the windfall (saving in an SWF). ${ }^{36}$ From this perspective, the resource windfall represents both a relaxation of the financing constraint and a new tax technology, in which we implicitly assume that low-income countries are in fact able to extract a high percentage of the rents associated with natural resource extraction. ${ }^{37}$

\section{Investing Volatile Resource Revenue}

The CEMAC application shows that the sustainable investing approach can address the exhaustibility issue when investing under a short revenue horizon. This section demonstrates how this approach can also manage volatility in the context of the Angola application. ${ }^{38}$ Given the long-lasting oil reserve

$\left(1 p_{t}^{N} Y_{t}^{N}\right.$ and $1 s_{t} Y_{t}^{T}$, see (equation 13)), the government is unable to use this as an additional source of fiscal revenue because these taxes do not appear as revenues in the budget constraint (equation (16)). On the other hand, taxes collected from the natural resource sector are accounted as a valid financing source for potential fiscal expenditures. Although this seems to be at odds with our assumptions about taxation of the nonresource sectors, it actually reflects some realistic tax-relevant characteristics of the extractive industries in developing economies.

${ }^{36}$ Among the investing scenarios investigated - all-investing in Figure 1, all-investing with sustaining capital through fiscal adjustments in Figure 2, and sustainable investing in Figure 3, welfare measures are all higher than saving in an SWF except the scenario of $\alpha^{G}=0.05$, where public capital is rather unproductive.

${ }^{37}$ International Monetary Fund (2012b) calculates that developing countries typically achieve effective tax rates in petroleum are on the order of 65-85 percent and in mining are 4565 percent.

${ }^{38}$ For Angola's recent economic conditions and oil production activity, see Chapter III.B of International Monetary Fund (2012d) and Richmond, Yackovlev, and Yang (2012). 
Figure 4. CEMAC Application: Investing Without a Resource Windfall
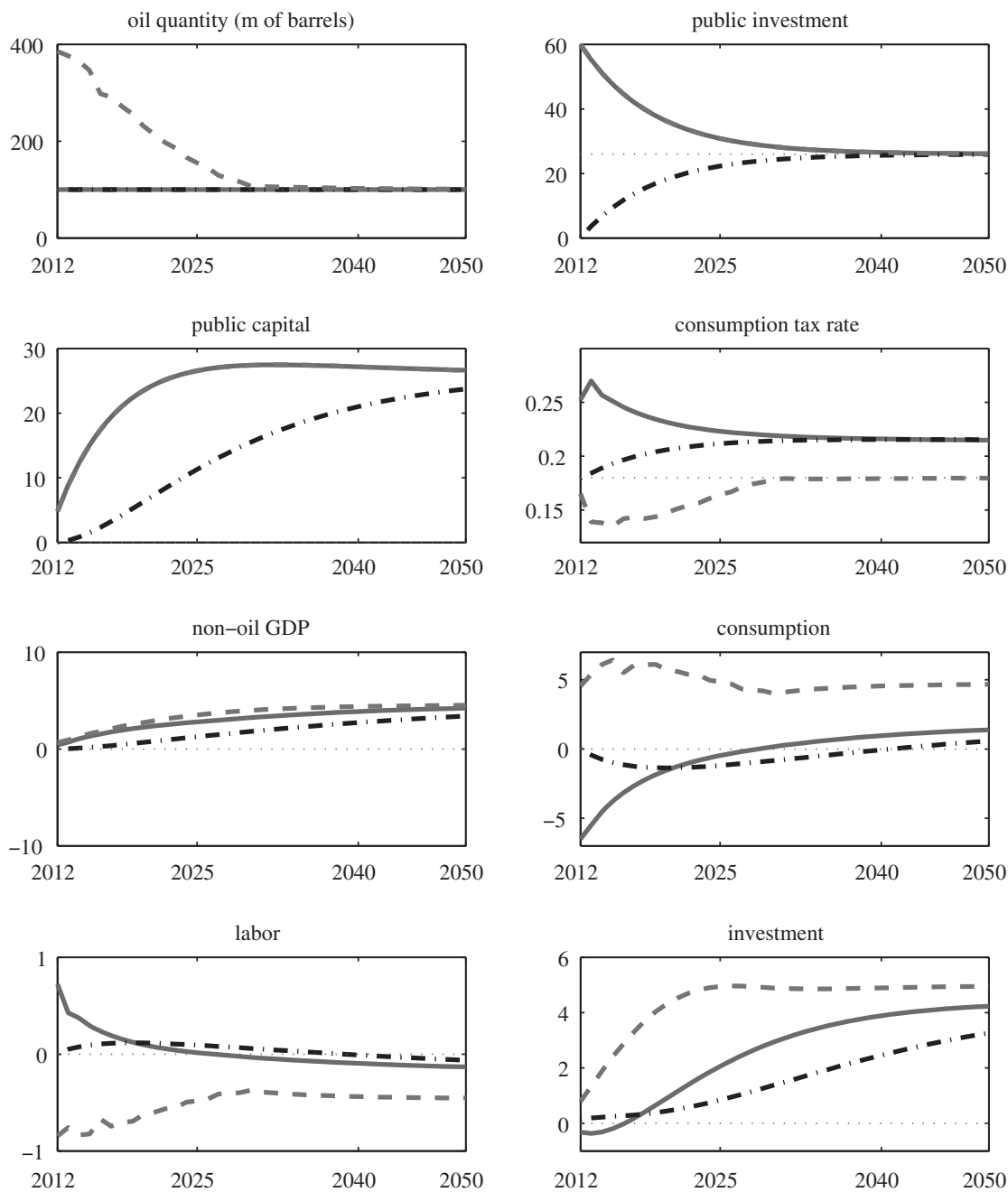

Solid and dotted-dashed lines assume a front-loaded and a gradual scaling-up path without a windfall, respectively; dashed lines assume a front-loaded scaling-up with a windfall. Y-axis is in percent deviation from the path without a windfall unless stated otherwise.

and more potential future findings in Angola, the initial steady state is calibrated to have high oil production. Revenue volatility is introduced by fluctuating oil prices mimicking historical dynamics. ${ }^{39}$

${ }^{39}$ Instead of obtaining a nonlinear perfect foresight solution as in CEMAC simulations, the equilibrium here is log-linearized and solved by Sims's (2001) method for rational expectations models. 


\section{The Sustainable Investing Approach to Managing Volatility}

With a long revenue horizon and high fiscal dependence on resource revenue, the resource fund analyzed for Angola is a stabilization fund, providing a fiscal buffer to smooth government spending. The policy rule for savings in a resource fund is revised to allow for depositing and withdrawing, as shown in Equation (25). For a given path of public investment and government consumption, surplus revenues, $\left(T_{t}^{O *}-T^{O_{*}}\right)-\left(p_{t}^{g} G_{t} / s_{t}-p^{g} G / s\right)$, are saved in a stabilization fund. Conversely, when there is a revenue shortfall, the fund is drawn down to maintain a level of investment commensurate with the given investment path. In the case of insufficient buffer, investment spending is cut to maintain a nonnegative balance in the fund. ${ }^{40}$ Technically, we impose a nonnegative constraint on the path of $F_{t}^{*}$.

To demonstrate the advantage of the sustainable investing approach in reducing macroeconomic instability, we compare the standard deviations of key variables under this approach with those under the spend-as-you-go approach. The latter follows the one analyzed in Richmond, Yackovlev, and Yang (2012) and is similar to what Angola has practiced until recently. Standard deviations reported in Table 3 are the average of 100 simulations based on different draws of price shock sequences $\left\{\varepsilon_{t}^{p o}\right\}$ from the estimated distribution. We take the projection of the oil production quantity in International Monetary Fund (2012d) as given, and a series of production shocks $\left\{\varepsilon_{t}^{y o}\right\}$ is injected to hit the projected quantity path. ${ }^{41}$ For our purpose, the analysis concerns about volatility in resource revenues (not the source of volatility). For simplicity, we use the same oil production path across simulations.

The spend-as-you-go approach is similar to the all-investing approach analyzed earlier. Instead of assuming that all resource revenues above the initial level go to investment, it is assumed that 60 percent of additional revenues goes to investment and the rest 40 percent goes to government consumption. With sustainable investing, we specify public investment to gradually increase from 8.7 percent of GDP (the actual level in 2011) to 15 percent in 2022. Given a high government consumption to GDP ratio in 2011 of 19.5 percent, we reduce government consumption and fixed it at 18 percent of GDP throughout the simulation horizon. Both the labor and consumption tax rates are set at their initial steady-state levels, while transfers experience small fluctuations to clear the government budget constraint.

\footnotetext{
${ }^{40}$ In practice, government consumption or transfers may also be reduced or tax rates may be raised to maintain an investment path. However, given the implementation difficulty in these other fiscal adjustment options, public investment is most likely to be cut, as observed recently in Angola.

${ }^{41}$ In Angola, aside from fluctuating oil price and quantities, oil revenue volatility is also due to unpredictable transfers of oil revenue from the state oil company to the treasury. See Box 6 in Chapter III.B of International Monetary Fund (2012d) for details.
} 
Table 3. Stabilization Effects of the Sustainable Investing Approach

\begin{tabular}{lcc}
\hline Variables & Spend-As-You-Go & Sustainable Investing \\
\hline Public investment & 16.2 & 7.4 \\
Nonresource GDP & 1.2 & 0.7 \\
Private consumption & 1.0 & 0.6 \\
Real exchange rate & 2.2 & 1.4 \\
\hline
\end{tabular}

Average standard deviation in percent from a de-trended path based on 100 simulations.

Table 3 compares the average standard deviations of public investment expenditure, private consumption, non-oil GDP, and the real exchange rate from 2011 to 2025 in percent deviations from their trend paths. All four variables exhibit more volatility - about 60-70 percent more-with spend-asyou-go. Despite a rather smooth investment path, public investment under the sustainable investing approach can still experience some fluctuations. When large negative revenue shocks hit, the stabilization fund may not have sufficient balance to support a predetermined investment level, forcing investment expenditures to dip, resulting in the adjustments in macroeconomic variables.

In an economy that is highly resource dependent, the fiscal channel through which resource revenue volatility can affect macroeconomic stability is made explicit here. Although the simulations assume that government purchases in Angola have a high share of traded goods $\left(v_{g}=0.2\right)$, the increased government purchases still generate some demand pressure on domestic production, driving up overall income and private consumption and investment. Conversely, when oil revenue declines, a procyclical fiscal policy as captured by spend-as-you-go can lead to a collapse of overall demand, generating a boom-bust cycle commonly observed in resource-rich economies. ${ }^{42}$ Sustainable investing, on the other hand, de-links periodic government spending from resource revenue flows, and thus shields the domestic economy from the disturbance of volatile resource revenues.

\section{Allocation between Investing and External Saving}

When following the sustainable investing approach, one question remains to answer: How large should a stabilization fund be in an environment of uncertain future revenue? A more aggressive scaling-up leads to faster build-up of public capital and potentially higher economic growth. As more resource revenue is devoted to investment, less can be saved, leaving the economy vulnerable to negative shocks. To address this policy question, we

\footnotetext{
${ }^{42}$ In addition to the experience of Angola from mid-2000s to 2010, Mongolia is another recent country example that experienced a boom-bust cycle with surges and falls in copper prices between 2006 and 2009. This led to a balance-of-payment crisis and, as a result of this, an IMF program to help stabilize the economy.
} 
show how stochastic simulations can be used to advise the allocation between investment and saving in a stabilization fund.

Figure 5 plots the one- and two-standard-deviation (68 and 95 percent) confidence intervals under two investment paths. The left column-the conservative scaling-up path - assumes that public investment and government consumption follow those assumed earlier (section "The Sustainable Investing Approach to Managing Volatility"). Relative to the left, the right column implements an aggressive scaling-up path. Public investment quickly rises from 9.2 percent in 2011 to 20 percent in 2016 and stays at this level for the rest of the simulation horizon.

The wide interval for oil prices (from $\$ 40$ to $\$ 180$ in 2025 ) captures the notorious fluctuations of oil price movements. Also, the very different performance of the stabilization fund confirms our conjecture that a more aggressive scaling-up plan leaves the economy with a small to little buffer. By the end of 2025, the stabilization fund is on average only 1.1 percent of GDP under the aggressive path, compared with the 37.1 percent under the conservative path. Since the stabilization fund is insufficient most of the time, the mean scaling-up magnitude from 2016 to 2025 at 15 percent also deviates much from the predetermined 20 percent. In contrast, the conservative path with a much larger buffer allows the realized investment path to follow closely the predetermined path. Without much disruption in the investment pace, the depreciation rate of public capital is also kept low in most cases. The average depreciation rate of the 95 percent upper bound is 0.08 under the conservative path, compared with 0.10 under the aggressive path.

The aggressive path on average accumulates more public capital (40 percent vs. 31 percent above the path without additional oil revenue at the end of 2025), but it also runs a much higher tail risk of accumulating less public capital. The one- (two-) standard-deviation lower band is $7.3(-27.0)$ percent with the aggressive path in 2025 vs. $24.8(-4.0)$ percent with the conservative path. When oil revenues are hit by a sequence of large negative oil shocks, the aggressive path, which does not have much buffer, cannot sustain investment even at the level to maintain existing capital, and hence public capital can fall below the initial steady-state level. Similar to the outcome with spend-as-you-go, large swings in public investment and hence public capital lead to great instability in the economy. As shown in Figure 5, the confidence intervals are wider for non-oil GDP under the aggressive path. The one-standard-deviation interval ranges from 5.0 to 22.0 percent above the path without additional oil revenue in 2025, compared with 7.5-15.0 percent with the conservative path. Moreover, despite a more stable economy with the conservative scaling-up path, households on average enjoy a similar magnitude of consumption as under the aggressive path.

The endogenous depreciation channel plays an important role in linking revenue shocks to macroeconomic volatility. Bad revenue outcomes imply investment well below replacement rates, resulting in an increase in depreciation rates, thus amplifying the effect of the negative shock on the capital stock and hence output. This can be seen in the very high upper band for the 
Figure 5. Angola Application: Conservative vs. Aggressive Scaling-Up under Sustainable Investing

oil price $(\$)$
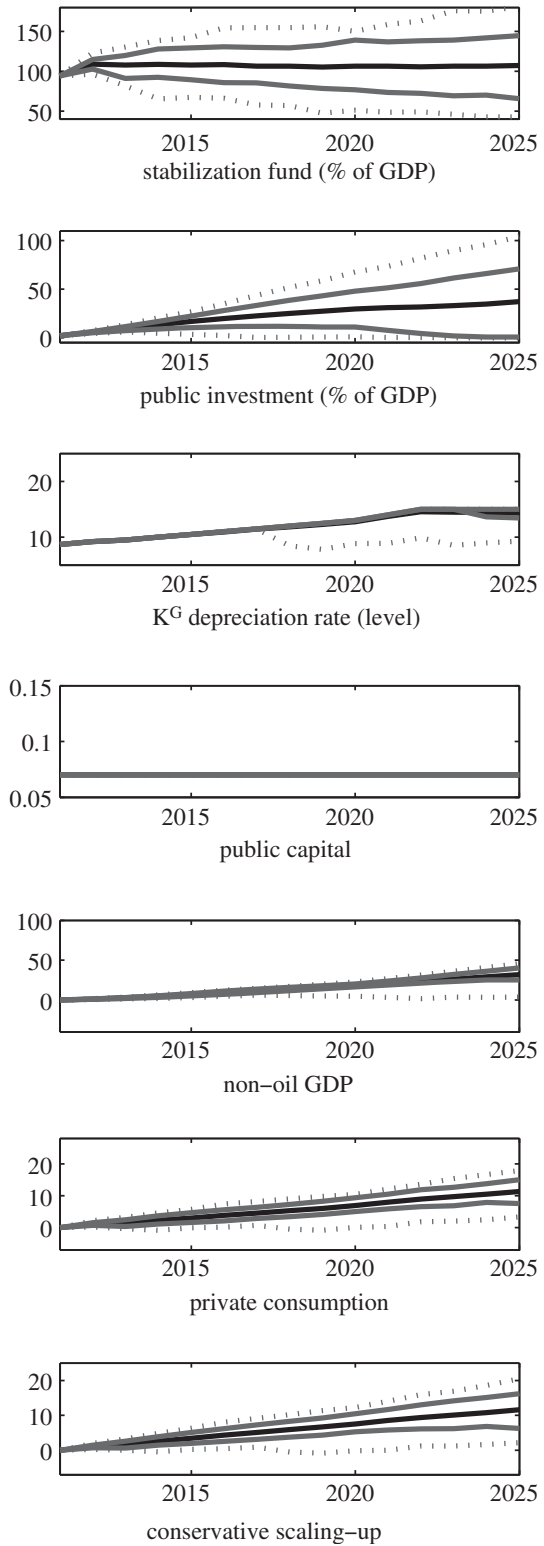

oil price (\$)
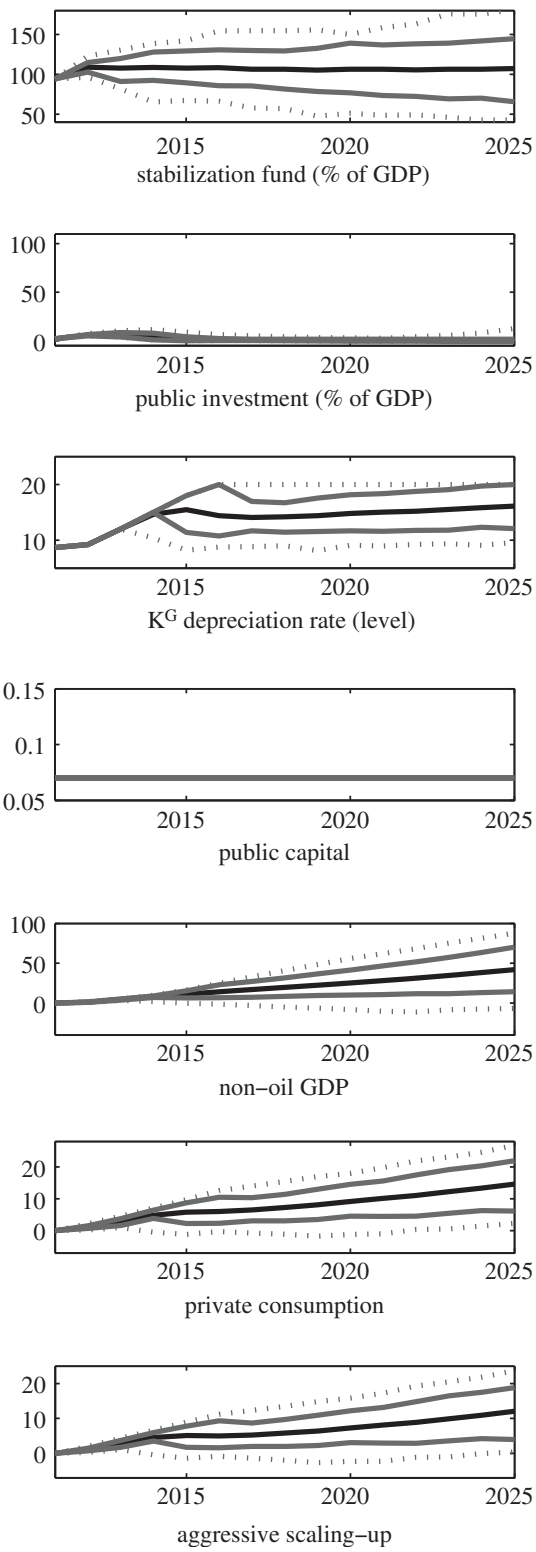

$\mathrm{Y}$-axis is in percent deviation from the path without a windfall unless stated otherwise. The middle solid lines are mean responses based on 100 simulations. The bands in solid lines are onestandard-deviation intervals, and the bands in dotted lines are two-standard-deviation intervals. 
depreciation rate in the case of aggressive scaling-up in Figure 5, which is one of the reasons for the substantially worse lower band for public capital, GDP, and so on.

The comparison of the two specific investment paths suggests that scaling up too much and too fast (as the aggressive path) could subject the economy to more instability, lowers investment efficiency, and there is no guarantee that its growth impact can outperform a more conservative scaling-up path. Our analysis can be extended to alternative investment paths under different parameter calibrations for a more thorough assessment in the adequacy of a stabilization fund.

\section{Conclusion}

Natural resource revenues provide an opportunity to accelerate economic development in capital-scarce economies that face financial and fiscal constraints. These revenues, however, pose significant challenges to policymakers as they are exhaustible and volatile. Using a small open DSGE small open model, we propose a "sustainable investing approach"combining investment with a resource fund - as a way to grapple with both exhaustibility and volatility. The approach makes possible to achieve development goals by scaling up public investment while maintaining economic stability. To illustrate this, we apply the model to the CEMAC region and Angola. In the CEMAC, the resource revenue horizon is short. The conversion of the windfall into permanently higher income is the key policy concern. In Angola, a highly resource-dependent economy with large reserves, managing (price) volatility is the priority.

The sustainable investing approach explicitly accounts for the financing needs involved in operating and preserving capital. The current literature on managing natural resources often neglects the fact that even if a government manages to build productive public capital by implementing good projects (implying high efficiency and absorptive capacity), its return will diminish over time unless revenues are available to cover recurrent costs. The failure to preserve public capital and cover recurrent costs has been an important theme in development public economics at least since Heller (1974) and remains of great practical significance. With limited revenue mobilization, our analysis implies that the size of the scaling-up plan should be jointly considered with an economy's ability to finance future costs to sustain capital and to the distorting effects of fiscal adjustments.

In cases where exhaustion lies beyond the horizon but resource revenue volatility looms large, sustainable investing avoids procyclical fiscal policy and minimizes the disruption in macroeconomic stability. Scaling up public investment too high and too fast-for example, following the path of resource revenues themselves - also lowers investment efficiency and risks higher depreciation rates. There is no guarantee that growth outcomes will be superior to a more conservative scaling-up path. In addition, it makes the economy more prone to boom-bust cycles. Sustainable investing, on the 
other hand, de-links periodic government spending from resource revenue flows, through a stabilization fund and thus shields the domestic economy from the disturbance of volatile resource revenues.

A number of extensions could usefully be considered. We focus on public investment in physical capital; the analysis can be extended to other types of investment, such as health and education to build human capital, which also improve the productivity of private inputs in production. We study some simple and implementable government rules; a fuller consideration of rulebased optimal policy, while not trivial in such a complex model, would clearly be useful. In addition, the model could readily be adapted to address short-run policy issues by introducing, for instance, nominal rigidities. Finally, natural resource booms can relax borrowing constraints, which may induce debt stability problems. ${ }^{43}$ As developing economies become more able to tap international bond markets, a detailed study of the interaction of natural resource revenues with fiscal rules that allow for accumulation of commercial debt is in order.

\section{REFERENCES}

Adler, J.H., 1965, Absorptive Capacity: The Concept and its Determinants (Washington, DC: Brookings Institution).

Agenor, R., and P. Montiel, 1999, Development Macroeconomic (2nd ed.) Princeton, NJ, Princeton University Press.

Araujo, J., B.G. Li, M. Poplawski-Ribeiro, and L.-F. Zanna, 2012, "Current Account Norms in Natural Resource Rich and Capital Scarce Economies," Manuscript, International Monetary Fund.

Arestoff, F., and C. Hurlin, 2006, "Estimates of Government Net Capital Stocks for 26 Developing Countries, 1970-2002," World Bank Policy Research Working Paper 3858.

Arezki, R., A. Dupuy, and A.H. Gelb, 2012, "Resource Windfalls, Optimal Public Investment and Redistribution: The Role of Total Factor Productivity and Administrative Capacity," IMF Working Paper 12/200 (Washington, DC: International Monetary Fund).

Bai, C.-E., and Y. Qian, 2010, "Infrastructure Development in China: The Cases of Electricity, Highways, and Railways," Journal of Comparative Economics, Vol. 38, No. 1, pp. 34-51.

Baker, C., and M. Nxumalo, 2013, "Assessing Reserve Adequacy of the Oil-Rich CEMAC Region: What Can We Learn from the 2008-09 Oil Price Shock?" IMF Working Paper (International Monetary Fund).

Barnett, S., and R. Ossowski, 2003, "Operational Aspects of Fiscal Policy in Oil-Producing Countries," in Fiscal Policy Formulation and Implementation in

\footnotetext{
${ }^{43}$ Manzano and Rigobon (2007), for instance, argue that during the 1970s, when commodities' prices were high, natural-resource-abundant countries used them as collateral for debt. As the 1980s witnessed an important fall in the prices, these countries faced debt crises. In this regard, the previously mentioned natural resource curse might be related to a debt overhang.
} 
Oil-Producing Countries, ed. by Davis J., Ossowski J., Fedelino A. (Washington, DC: International Monetary Fund).

Baunsgaard, T., M. Villafuerte, M. Poplawski-Ribeiro, and C. Richmond, 2012, "Fiscal Framework for Natural Resource Intensive Developing Countries," IMF Staff Discussion Note 12/04.

Baxter, M., and R.G. King, 1993, "Fiscal Policy in General Equilibrium," American Economic Review, Vol. 86, No. 3, pp. 1154-74.

Bems, R., and I. de Carvalho Filho, 2011, "The Current Account and Precautionary Savings for Exporters of Exhaustible Resources," Journal of International Economics, Vol. 84, No. 1, pp. 48-64.

Berg, A., J. Gottschalk, R. Portillo, and L.-F. Zanna, 2010, "The Macroeconomics of Medium Term Aid Scaling-Up Scenarios," IMF Working Paper 10/160 (Washington, DC: International Monetary Fund).

Berg, A., R. Portillo, S.-C.S. Yang, and L.-F. Zanna, 2012, "Public Investment in Resource Abundant Developing Countries," IMF Working Paper 12/274 (International Monetary Fund).

Berg, E., 1983, Absorptive Capacity in the Sahel Countries (Paris: OECD).

Buffie, E.F. and others 2012, "Public Investment, Growth, and Debt Sustainability: Putting Together the Pieces," IMF Working Paper 12/144 (International Monetary Fund).

Burstein, A., M. Eichenbaum, and S. Rebelo, 2005, "Large Devaluations and the Real Exchange Rate," Journal of Political Economy, Vol. 113, No. 4, pp. 742-84.

Caceres, C., M. Poplawksi-Ribeiro, and D. Tartari, 2011, "Inflation Dynamics in the Cemac Region,” IMF Working Paper 11/232 (Washington, DC: International Monetary Fund).

Chenery, H.B., and A. Strout, 1966, "Foreign Assistance and Economic Development," American Economic Review, Vol. 56, No. 4, pp. 679-733.

Cherif, R., and F. Hasanov, 2012, "Oil Exporters' Dilemma: How Much to Save and How Much to Invest," IMF Working Paper 12/4 (Washington, DC: International Monetary Fund).

Collier, P., 2009, "Still the Bottom Billion," Finance and Development, June 4-7, interview with Glenn Gottselig.

Collier, P., R. van der Ploeg, M. Spence, and A.J. Venables, 2010, "Managing Resource Revenues in Developing Economies," IMF Staff Papers, Vol. 51, No. 7, pp. $84-118$.

Cubas, C., 2011, "Accounting for Cross-Country Income Differences with Public Capital," Manuscript, Central Bank of Uruguay.

Daban, T., and J.-L. Helis, 2010, "A Public Financial Management Framework for Resource Producing Countries," IMF Working Paper 10/72 (Washington, DC: International Monetary Fund).

Dabla-Norris, E. and others 2011, "Investing in Public Investment: An Index of Public Investment Efficiency," IMF Working Paper 11/37 (Washington, DC: International Monetary Fund).

Dagher, J., J. Gottschalk, and R. Portillo, 2012, "Oil Windfalls in Ghana: A DSGE Approach," Journal of African Economies, Vol. 21, No. 3, pp. 343-72.

Davis, J., J. Ossowski, J. Daniel, and S. Barnett, 2001, "Stabilizing and Saving Funds for Nonrenewable Resources: Experience and Fiscal Policy Implications," IMF Occasional Paper No. 205 (Washington, DC: International Monetary Fund). 
Energy Information Administration, 2012, Country Analysis Briefs (Washington, DC: Energy Information Administration).

Gelb, A.H., 1988, Oil Windfalls: Blessing or Curse (Oxford, UK: Oxford University Press, a World Bank Research Publication).

Goldberg, J., 2011, "Kwacha Gonna Do? Experimental Evidence about Labor Supply in Rural Malawi," Manuscript, Economics Department, University of Maryland.

Gourinchas, P.-O., and O. Jeanne, forthcoming, "Capital Flows to Developing Countries: The Allocation Puzzle," Review of Economic Studies.

Greenwood, J., Z. Hercowitz, and G.W. Huffman, 1988, "Investment, Capacity Utilization, and the Real Business Cycle," American Economic Review, Vol. 78, No. 3, pp. $402-17$.

Gros, D., and T. Mayer, 2012, “A Sovereign Wealth Fund to Lift Germany's Curse of Excess Savings," CEPS Policy Brief No. 280, August 28, Centre for European Policy Studies.

Gupta, S., A. Kangur, C. Papageorgiou, and A. Wane, 2011, "Efficiency-Adjusted Public Capital and Growth," IMF Working Paper 11/217 (Washington, DC: International Monetary Fund).

Hamilton, J.D., 2009, “Understanding Crude Oil Prices," Energy Journal, Vol. 30, No. 2, pp. 179-206.

Heller, P.S., 1974, "Public Investment in LDC's with Recurrent Cost Constraint: The Kenyan Case," Quarterly Journal of Economics, Vol. 88, No. 2, pp. 251-77.

_ 1979, "The Underfinancing of Recurrent Development Costs," Finance and Development, March, Vol. 16, No. 1, pp. 38-41.

Horvat, B., 1958, "The Optimal Rate of Investment," Economic Journal, Vol. 68, No. 272, pp. 47-67.

Horvath, M., 2000, "Sectoral Shocks and Aggregate Fluctuations," Journal of Monetary Economics, Vol. 45, No. 1, pp. 69-106.

Hurlin, C., and F. Arestoff, 2010, “Are Public Investment Efficient in Creating Capital Stocks in Developing Countries?” Economics Bulletin, Vol. 30, No. 4, pp. 3177-87.

Independent Evaluation Office, 2011, "Research at the IMF: Relevance and Utilization," Background Papers, May. International Monetary Fund, Washington, D.C.

International Bank for Reconstruction and Development and the World Bank, 2010, Cost-Benefit Analysis in World Bank Projects (Washington, DC: The International Bank for Reconstruction and Development, The World Bank).

International Development Association and International Monetary Fund, 2011, Heavily Indebted Poor Countries (HIPC) Initiative and Multilateral Debt Relief Initiative (MDRI)—Status of Implementations and Proposals for the Future of the HIPC Initiative (Washington, DC: International Development Association and International Monetary Fund).

International Monetary Fund, 2009, "Debt Limits in Fund-Supported Programs: Proposed New Guidelines," SM/09/215. Washington, D.C.

- 2011, Revenue Mobilization in Developing Countries (Washington, DC: International Monetary Fund).

2012a, Enhancing Financial Sector Surveillances in Low-Income Countries: Financial Deepening and Macro-Stability (Washington, DC: International Monetary Fund). 
, 2012b, Fiscal Regimes for Extractive Industries: Design and Implementation (Washington, DC: International Monetary Fund).

, 2012c, Macroeconomic Policy Frameworks for Resource-Rich Developing Countries (Washington, DC: International Monetary Fund).

_ 2012d, Macroeconomic Policy Frameworks for Resource-Rich Developing Countries-Analytic Frameworks and Applications (Washington, DC: International Monetary Fund).

_ 2012e, "World Economic Outlook: Growth Resuming, Dangers Remain," April (Washington, DC: International Monetary Fund).

Kamps, C., 2004, The Dynamic Macroeconomic Effects of Public Capital (Berlin, Germany: Springer).

Kim, N., 2007, "The Impact of Remittances on Labor Supply: The Case of Jamaica," World Bank Policy Research Working Paper No. 4120.

Kraay, A., 2012, "How Large is the Government Spending Multiplier? Evidence from World Bank Lending," Quarterly Journal of Economics, Vol. 127, No. 2, pp. 829-87.

Lucas, R., 1990, “Why Doesn't Capital Flow from Rich to Poor Countries?” American Economic Review Papers and Proceedings, Vol. 80, No. 2, pp. 92-6.

Manzano, O., and R. Rigobon, 2007, "Resource Curse or Debt Overhang," in Natural Resources: Neither Curse nor Destiny, ed. by Lederman D. and Maloney W.F. (Washington, DC: The World Bank).

Moreno, M.A., and C.A. Shelton, 2013, "Sleeping in the Bed One Makes: The Venezuelan Fiscal Policy Response to the Oil Boom," in Venezuela: Anatomy of a Collapse, ed. by Hausmann R. and Rodriguez F. (University Park, Pennsylvania: Penn State University Press).

Pieschacon, A., 2011, "The Value of Fiscal Discipline in Oil-Exporting Countries," Journal of Monetary Economics, Vol. 59, No. 3, pp. 250-68.

Pritchett, L., 2000, "The Tyranny of Concepts: Cudie (Cumulated, Depreciated, Investment Effort) is Not Capital," Journal of Economic Growth, Vol. 5, No. 4, pp. 361-84.

Richmond, C.J., I. Yackovlev, and S.-C.S. Yang, 2012, "Investing Volatile Oil Revenue in Capital Scarce Economies: An Application to Angola," Manuscript, International Monetary Fund.

Rioja, F.K., 2003, "Filling Potholes: Macroeconomic Effects of Maintenance Versus New Investments in Public Infrastructure," Journal of Public Economics, Vol. 87, No. 9-10, pp. 2281-304.

Sachs, J.D., 2007, "Chapter 7: How to Handle the Macroeconomics of Oil Wealth?" in Escaping the Resource Curse, ed. by Humphreys M., Sachs J.D., and Stiglitz J.E. (New York: Columbia University Press).

Sachs, J.D., and A.M. Warner, 1999, "The Big Push, Natural Resource Booms and Growth," Journal of Development Economics, Vol. 59, No. 1, pp. 43-76.

- 2001, "The Curse of Natural Resources," European Economic Review, Vol. 45, No. 4-6, pp. 827-38.

Shi, Y., 2012, "The Role of Infrastructure Capital in China's Regional Economic Growth," Manuscript, Michigan State University.

Sims, C.A., 2001, "Solving Linear Rational Expectations Models," Journal of Computational Economics, Vol. 20, No. 1-2, pp. 1-20. 
Stockman, A.C., and L.L. Tesar, 1995, "Tastes and Technology in a Two-Country Model of the Business Cycle: Explaining International Comovements," American Economic Review, Vol. 85, No. 1, pp. 168-85.

Takizawa, H., E.H. Gardner, and K. Ueda, 2004, "Are Developing Countries Better off Spending their Oil Wealth Upfront?" IMF Working Paper 04/141 (Washington, DC: International Monetary Fund).

UNCTAD, 2012, "World Investment Report: Towards a New Generation of Investment Policies," United Nations, Geneva.

UNCTAD Secretariat, 2006, "Boosting Africa's Growth Through Re-Injecting "Surplus" Oil Revenue: An Alternative to the Traditional Advice to Save and Stabilize," Tech. rep. (The United Nations Conference on Trade and Development), July 28.

Van den Bremer, T.S., and F. van der Ploeg, 2012, "How to Spend a Windfall: Dealing with Volatility and Capital Scarcity," OxCarre Research Paper 85.

van der Ploeg, F., 2010a, "Why do Many Resource-Rich Countries have Negative Genuine Savings? Anticipation of Better Times or Rapacious Rent Seeking," Resource and Energy Economics, Vol. 32, No. 1, pp. 28-44.

, 2011, "Natural Resources: Curse or Blessing? Journal of Economic Literature, Vol. 49, No. 2, pp. 366-420.

_ 2012, "Bottlenecks in Ramping Up Public Investment," International Tax and Public Finance, Vol. 19, No. 4, pp. 509-38.

van der Ploeg, F., R.R. Stefanski, and S. Wills, 2012, "Harnessing Oil Revenues in Ghana," International Growth Center Working Paper 12/0034.

van der Ploeg, F., and A.J. Venables, 2011, "Harnessing Windfall Revenues: Optimal Policies for Resource-Rich Developing Economies," The Economic Journal, Vol. 121, No. 551, pp. 1-30.

van der Ploeg, R., 2010b, "Aggressive Oil Extraction and Precautionary Saving: Coping with Volatility," Journal of Public Economics, Vol. 94, No. 5-6, pp. 421-33.

van Wijnbergen, S., 1984, "The 'Dutch Disease': A Disease After All?" The Economic Journal, Vol. 94, No. 1, pp. 41-55.

Venables, A.J., 2010, "Resource Rents; When to Spend and How to Save," International Tax and Public Finance, Vol. 17, No. 4, pp. 340-56.

World Bank, 1994, World Development Report 1994: Infrastructure for Development (Washington, DC: The World Bank). 